\title{
A DITADURA MILITAR E O BIPARTIDARISMO: casuísmos e um simulacro de democracia
}

\author{
Alessandro Batistella*
}

\begin{abstract}
RESUMO: A ditadura militar de Segurança Nacional implantada no Brasil em 1964 procurou legitimar-se por meio de um contraditório arcabouço jurídico-institucional que, apesar da aparência de legalidade, impôs um sistema de censura, vigilância e repressão baseado no Terrorismo de Estado. Ao hipertrofiar os poderes dos generais-presidentes e restringir a autonomia do Legislativo e do Judiciário, o regime procurou camuflar a ditadura, inclusive criando um simulacro de democracia, caracterizado por um sistema político bipartidário artificial, por inúmeros casuísmos, pelas eleições indiretas e o jogo de cartas marcadas, pelas cassações de políticos dissidentes e oposicionistas e pelo fechamento temporário do Congresso em três oportunidades. Dessa forma, o objetivo desse artigo é analisar as contradições do simulacro de democracia criado pela ditadura militar.

PALAVRAS CHAVE: Ditadura militar; Bipartidarismo; Casuísmo; Autoritarismo.
\end{abstract}

\section{The military dictatorship and bipartisanship: casuistry and a simulacrum of democracy}

ABSTRACT: The military dictatorship of National Security implemented in Brazil in 1964 sought to legitimize itself through a contradictory legal-institutional framework that despite the appearance of legality imposed a system of censorship, surveillance and repression based on State Terrorism. By hypertrophying the powers of the general presidents and restricting the autonomy of the Legislative and Judiciary, the regime sought to camouflage the dictatorship, including by creating a simulacrum of democracy, characterized by an artificial bipartisan political system, by countless casuistry, by indirect elections and the game of marked letters, the impeachment of dissidente and opposition politicians and the temporary closure of Congress on three occasions. Thus, the objective of this article is to analyze the contradictions of the simulacrum of democracy created by the military dictatorship.

KEYWORDS: Military dictatorship; Bipartisanship; Casuistry; Authoritarianism.

\section{La dictadura militar y bipartidarismo: casuística y simulacro de democracia}

RESUMEN: La dictadura militar de la Seguridad Nacional implantada en Brasil en 1964 buscó legitimarse a través de un marco jurídico-institucional contradictorio que, a pesar de la apariencia de legalidad, impuso un sistema de censura, vigilancia y represión basado en el terrorismo de Estado. Al hipertrofiar los poderes de los generales-presidentes y restringir la autonomía del Legislativo y Judicial, el régimen buscó camuflar la dictadura, incluso creando un simulacro de democracia, caracterizado por un sistema político bipartidista artificial, por innumerables casuismos, por elecciones indirectas y el juego de letras marcadas, la acusación de políticos disidentes y opositores y el cierre temporal del Congreso en tres ocasiones. Así, el objetivo de este artículo es analizar las contradicciones del simulacro de democracia creado por la dictadura militar.

PALABRAS CLAVE: Dictadura militar; Bipartidismo; Casuismo; Autoritarismo.

\footnotetext{
*Doutor em História pela Universidade Federal do Rio Grande do Sul. Atualmente é professor do curso de História e do Programa de Pós-Graduação em História da Universidade de Passo Fundo. Contato: BR 285, CEP: 99052-900, Passo Fundo/RS, Brasil. E-mail: alessandrobatistella@yahoo.com.br. Orcid: https://orcid.org/00000003-4606-8249
} 


\section{Considerações Iniciais}

Após o golpe civil-militar de 1964, implantou-se no Brasil uma ditadura militar de Segurança Nacional ${ }^{1}$ que buscou legitimar-se por meio de uma fachada jurídica, a partir de uma série de Atos Institucionais e de Atos Complementares ${ }^{2}$, além de praticamente outorgar a Constituição de 1967, criando um sistema político híbrido: não foram extintos os poderes Legislativo e Judiciário, embora seus poderes e autonomia tenham sido restringidos consideravelmente; mantiveram-se abertos, embora perifericamente, alguns canais de participação política aos civis, ao mesmo tempo em que se edificou um sistema político extremamente fechado no tocante às decisões essenciais - que ficaram restritas aos militares; não foram eliminadas as eleições parlamentares, mas instituíram-se as eleições indiretas para presidente da República e governadores estaduais ${ }^{3}$.

Esse tortuoso e contraditório arcabouço jurídico visava a camuflar a implantação da ditadura de Segurança Nacional. Afinal, o golpe de 1964 procurou legitimar-se com o discurso de que se tratava de uma "revolução preventiva e redentora", que salvou o Brasil de um suposto golpe comunista em marcha, garantindo, assim, a manutenção das liberdades democráticas. Desse modo, assumir declaradamente a quebra da ordem constitucional e a implantação de uma ditadura no país catalisaria reações e críticas da opinião pública nacional e internacional. Ademais, deve-se ressaltar a própria natureza do golpe de 1964, cujos conspiradores e apoiadores civis e militares possuíam diferentes aspirações pessoais e projetos políticos, mas uniram-se para derrubar João Goulart, concordando com a necessidade de um governo militar temporário (isto é, até 31 de janeiro de 1966, para completar o mandato de Jango) para "sanear a democracia" e combater a "subversão e a corrupção". 4

No entanto, contrariando os que imaginaram que se tratava de apenas mais uma breve intervenção militar na história brasileira, o golpe de 1964 instaurou uma longa ditadura, que durou mais de 21 anos (1964-1985). Nesse sentido, concordamos com Adriano Codato de que a ditadura militar brasileira durou 25 anos (1964-1989) - incluindo o governo civil de José Sarney - e a sua história pode ser dividida em cinco fases ${ }^{5}$ :

- Primeira fase: constituição do regime político ditatorial-militar (1964-1968): corresponde aos governos Castelo Branco (1964-1967) e Costa e Silva, caracterizada pela decretação de cinco Atos Institucionais, que serviram para a "normatização autoritária". 
- Segunda fase: consolidação do regime ditatorial-militar (1969-1974): coincide com o governo do general-presidente Emílio Garrastazu Médici e com o auge da ditadura militar e da repressão.

- Terceira fase: transformação do regime ditatorial-militar (1974-1979): corresponde ao governo do general-presidente Ernesto Geisel e o projeto de distensão política e institucionalização/constitucionalização do regime.

- Quarta fase: desagregação do regime ditatorial-militar (1979-1985): coincide com o governo do general-presidente João Batista Figueiredo e com a continuidade do projeto de distensão política (agora chamado de "abertura"), mas, sobretudo, com o processo de decrepitude da ditadura, que se acentuou a partir de 1983.

- Quinta fase: transição do regime ditatorial-militar para o regime liberal-democrático (1985-1989): corresponde ao governo do civil José Sarney (político alinhado com a ditadura), concretizando o processo de transição pactuada ${ }^{6}$ iniciado em 1983. Nessa fase de transição, sob tutela militar, ocorreu a formação da Assembleia Nacional Constituinte (1987-1988), a promulgação da Constituição de 1988 e as eleições direitas de 1989 à presidência da República. Com a posse do presidente eleito Fernando Collor de Mello, em março de 1990, tem efetivamente início o regime liberal-democrático.

Contudo, a ditadura militar brasileira se estruturou a partir das diretrizes da Doutrina de Segurança Nacional, das orientações estratégicas da teoria da contra-insurgência norteamericana e da doutrina de guerra revolucionária francesa ${ }^{7}$, instituindo, assim, a noção de "guerra interna". Dessa forma, a ditadura militar de Segurança Nacional implantada no Brasil a partir de 1964 criou o "inimigo interno" - chamado genericamente de "subversivo" -, adotando sistematicamente uma política repressiva baseada no Terrorismo de Estado.

Conforme Miguel Bonasso, o Terrorismo de Estado demarca um modelo de Estado contemporâneo que ultrapassa os limites da "repressão legal" (permitida pelo arcabouço jurídico-constitucional) e se utiliza de "métodos não convencionais" (tais como o sequestro, a detenção ilegal, a tortura, o assassinato e o desaparecimento de opositores e seus cadáveres) para aniquilar a oposição política e o protesto social, sejam estes armados ou desarmados ${ }^{9}$.

Segundo Enrique Serra Padrós, o Terrorismo de Estado foi um sistema específico de poder das ditaduras latino-americanas de Segurança Nacional, no qual a imposição de ações coercitivas ou "pedagógicas" do Estado repressivo produziu o medo dissuasivo através de mecanismos variados e eficientes (físicos, psicológicos, econômicos) ${ }^{10}$. Dessa forma, a 
ditadura militar de Segurança Nacional brasileira, por meio do uso sistemático do Terrorismo de Estado, consolidou uma "cultura do medo"11", a lógica da "suspeição" - isto é, todos eram suspeitos de serem potenciais "inimigos internos" - e uma política de controle e de restrições às liberdades de expressão (por meio da censura), manifestação e reunião.

No que tange ao sistema político-partidário no Brasil, a ditadura militar inicialmente não fechou os partidos políticos em vigência no país desde 1945, embora tenha expurgado seus elementos considerados "subversivos e corruptos". Porém, em outubro de 1965, com o Ato Institucional $\mathrm{n}^{\circ} 2$ (AI-2), a ditadura extinguiu os partidos políticos existentes e o próprio sistema pluripartidário. Como a ditadura pretendia implantar um simulacro de democracia, não cairia bem proibir a existência de partidos políticos e nem adotar o modelo de partido único (associado às ditaduras monopartidárias). Desse modo, a alternativa adotada foi a criação de um novo sistema partidário bipartidário, que durou até o final de 1979.

Se, por um lado, interessava à ditadura criar um forte partido de apoio ao regime, que lhe garantisse uma base parlamentar sólida, por outro, também era interessante permitir a criação de um pequeno, fraco, dócil e "bem comportado" partido oposicionista. Desse modo, foram organizados o partido governista, denominado de Aliança Renovadora Nacional (ARENA), e o partido oposicionista, denominado Movimento Democrático Brasileiro (MDB).

Portanto, o bipartidarismo foi um sistema artificial resultante do autoritarismo da ditadura militar, no qual a ARENA, com servilismo, referendava as decisões dos generaispresidentes, enquanto o MDB deveria desempenhar uma inócua oposição. Nesse teatro, quem não cumprisse o papel que the foi originalmente destinado a desempenhar era enquadrado pela ditadura, que se utilizou dos Atos Institucionais para cassar parlamentares da ARENA e, sobretudo, do MDB. Ademais, nos momentos em que o Congresso ultrapassou determinados limites impostos pela ditadura, acabou sendo fechado temporariamente em três ocasiões (1966, 1968-1969 e 1977).

Outros elementos amplamente utilizados pela ditadura foram os casuísmos, isto é, as manobras realizadas para garantir o controle do sistema político, como as mudanças das regras eleitorais para garantir a vitória eleitoral da ARENA. O casuísmo foi utilizado em 1966, para evitar a derrota do candidato arenista ao governo do Rio Grande do Sul nas eleições indiretas. Posteriormente, com o crescimento eleitoral do MDB em 1974, os casuísmos se multiplicaram, com a Lei Falcão, o "Pacote de Abril" e a própria reforma 
político-partidária de 1979 que determinou o fim do bipartidarismo visando à fragmentação da oposição.

Com o Legislativo e o Judiciário com pouquíssima autonomia, os generais-presidentes tiveram amplos poderes para governar o país de maneira autoritária, inclusive escolhendo os governadores estaduais da sua confiança. Por sua vez, os governadores tinham a prerrogativa de nomear os prefeitos das capitais e dos municípios considerados áreas de segurança nacional.

Em virtude do crescente negacionismo histórico da ditadura militar brasileira, que tem ecoado atualmente no país, o objetivo desse artigo é analisar as contradições do simulacro de democracia criado pela ditadura militar de Segurança Nacional para legitimar-se, camuflandose por meio de um arcabouço jurídico autoritário que impôs um sistema de censura, vigilância e repressão baseado no Terrorismo de Estado.

\section{Do golpe à ditadura: Castelo Branco e a construção da ordem autoritária}

Após o golpe civil-militar de 1964 e a deposição do presidente João Goulart, os primeiros dias de abril foram marcados pelas incertezas e pelas disputas pelo poder. $\mathrm{Na}$ madrugada do dia 2 de abril, Ranieri Mazzilli, presidente da Câmara dos Deputados, era empossado como presidente da República. Também no dia 2 de abril, o general Arthur da Costa e Silva autonomeou-se comandante do Exército Nacional, por ser o mais antigo general de quatro estrelas, e cria o Comando Supremo da Revolução, composto pelo próprio Costa e Silva (Exército), o brigadeiro Francisco de Assis Correia de Melo (Aeronáutica) e o vicealmirante Augusto Rademaker Grünewald (Marinha). Em seguida, o general Costa e Silva autonomeia-se ministro da Guerra e torna-se o homem forte do novo regime, inclusive enquadrando o presidente em exercício Ranieri Mazzilli, que não controlava a situação.

Ainda no início de abril, os "governadores revolucionários ${ }^{12}$ " definiram-se pela não permanência de Mazzilli e pela indicação do nome do marechal Humberto de Alencar Castelo Branco $^{13}$ para a presidência da República. Embora Castelo Branco contasse com o apoio da maioria dos oficiais do Exército, o general Costa e Silva se mostrava disposto à manutenção de Mazzilli como "presidente fantoche", pois assim, na prática, seria o real detentor do $\operatorname{poder}^{14}$.

Assim, durante as tensas reuniões entre os governadores e o ministro da Guerra, realizadas nos dias 4 e 5 de abril de 1964, no Rio de Janeiro, Costa e Silva inicialmente insurgiu-se contra o lançamento da candidatura de Castelo Branco. Porém, mesmo 
contrariado, acabou aceitando a candidatura do chefe do Estado-Maior do Exército após uma reunião do Alto Comando. Dessa forma, Castelo Branco chegaria ao poder graças ao prestígio que desfrutava entre os setores militares e também pelo apoio que recebeu dos "governadores revolucionários" e de outras lideranças civis.

No dia 9 de abril de 1964, o Comando Supremo da Revolução - que, na prática, governava o país - decretou o Ato Institucional n ${ }^{\circ} 1$ (AI-1) que, entre outras coisas, reforçou o Poder Executivo e reduziu o campo de ação do Congresso, estabeleceu a eleição de um novo presidente da República por votação indireta do Congresso Nacional e suspendeu as imunidades parlamentares, dando início à série de cassações de mandatos parlamentares e suspensões dos direitos políticos por dez anos - com o objetivo de "limpar" o Congresso, cassando os mandatos de parlamentares acusados de subversão ou de corrupção. O AI-1 também permitia ao regime aplicar uma série de sanções (como exonerar, demitir, aposentar, transferir para a reserva, entre outros) a militares, funcionários públicos, juízes, professores, dando início a "Operação Limpeza", que visava a promover o expurgo de civis e militares alinhados com João Goulart e/ou com as bandeiras reformistas e nacionalistas.

Conforme observa Carlos Fico, a disputa pelo poder, que apareceu em versão condensada na reunião de Costa e Silva e os governadores, e a decretação do AI-1, que institucionalizou o golpe - dando uma aparência de licitude ao novo regime -, marcam a passagem do golpe à ditadura, com as Forças Armadas tomando o controle do Estado e delegando aos seus aliados civis um papel de coadjuvantes ${ }^{15}$.

No dia 11 de abril de 1964, o marechal Castelo Branco foi eleito pelo Congresso como o novo presidente da República, sendo empossado no dia 15 de abril ${ }^{16}$. Contudo, durante os primeiros meses do governo Castelo Branco percebe-se a existência de divisões e de disputas internas dentro das Forças Armadas entre os "castelistas" - denominados de "Sorbonne militar", esse grupo aglutinava nomes como os generais Golbery do Couto e Silva, Ernesto Geisel, Orlando Geisel e demais militares vinculados às ideias e diretrizes da Escola Superior de Guerra $(E S G){ }^{17}$ - e os seus opositores, denominados de "linha dura".

De acordo com Maud Chirio, a categoria "linha dura" surgiu do vocabulário dos próprios atores e não tinha, no princípio, o sentido de grupo ou facção para os oficiais que a reivindicavam, mas sim de certa interpretação da "revolução", de um "estado de espírito", cuja linha política tinha contornos imprecisos. Portanto, a princípio, a "linha dura" não passava de uma maneira de expressar oposição a Castelo Branco ${ }^{18}$. Conforme a pesquisadora, os anos de 1964 e 1965 são considerados o período de incubação da "linha dura", que 
funcionaria como um forte grupo de pressão. Trata-se de um grupo heterogêneo, que emitia um discurso de extrema-direita e nacionalista e defendia a proposta de um expurgo radical, "sem consideração pelos procedimentos adotados e nem pela conformidade com a lei". Nesse sentido, os oficiais da "linha dura" são os principais defensores da violência de Estado e da repressão política ${ }^{19}$.

Embora seja considerado um liberal e moderado por alguns jornalistas e historiadores $^{20}$, não se pode negligenciar o caráter autoritário e repressivo do governo do marechal-presidente Castelo Branco, caracterizado pela construção da ordem jurídicoinstitucional autoritária. De fato, durante o seu governo foram decretados quatro Atos Institucionais, uma Lei de Imprensa restritiva, criou-se o Serviço Nacional de Informações (SNI), fechou o Congresso por 32 dias e outorgou a Constituição de $1967^{21}$. Além disso, ajudou a redigir e assinou a Lei de Segurança Nacional - estruturada nas diretrizes da Doutrina de Segurança Nacional e na doutrina de guerra revolucionária, instituindo a noção de guerra interna - e foi conivente com a tortura ${ }^{22}$, que já era praticada nos primeiros momentos após o golpe ${ }^{23}$.

No que tange à repressão, no governo Castelo Branco milhares de oponentes civis e militares foram perseguidos, presos, humilhados em público e torturados, frequentemente sem processo legal ${ }^{24}$. Soma-se a isso o número considerável de mortos e desaparecidos políticos ${ }^{25}$, o que demonstra que o Terrorismo de Estado foi implantado desde 1964. Ademais, no governo Castelo Branco o expurgo foi voraz, sendo o general-presidente que mais aplicou sanções aos "inimigos do regime" com base nos Atos Institucionais: dos 5.517 punidos por esse tipo de ato, 65\% (3.644) foram durante o seu governo. Convém ressaltar que $90 \%$ dos expurgos a militares ocorreram durante o governo de Castelo Branco ${ }^{26}$.

Pressionado pela "linha dura" para que o seu mandato presidencial fosse ampliado, Castelo Branco aceitou que a medida fosse aprovada no Congresso em julho de 1964. Dessa forma, o mandato presidencial de Castelo Branco foi prorrogado por 14 meses, isto é, até 15 de março de 1967, o que representou o adiamento das eleições diretas à presidência da República previstas para 1965. Embora procurasse construir uma imagem de "legalista", Castelo Branco rompeu o compromisso assumido em manter as eleições presidenciais de 1965, desagradando Carlos Lacerda e marcando o início do seu processo de afastamento de Castelo Branco. 


\section{A crise político-militar, o AI-2 e a implantação do bipartidarismo}

No dia 3 de outubro de $1965^{27}$, estavam previstas eleições diretas para os governos de 11 estados da federação. Contudo, ao longo do ano de 1965, os militares da "linha dura" e os governadores Carlos Lacerda e Magalhães Pinto (que ambicionavam concorrer à presidência em 1966 e temiam perder o controle sobre as máquinas dos governos estaduais para os seus adversários políticos) empreenderam uma forte pressão para que as eleições fossem adiadas e que os mandatos dos governadores fossem prorrogados por mais um ano.

No entanto, o marechal-presidente Castelo Branco optou em manter as eleições diretas de outubro de 1965 para os governos estaduais. No referido pleito, Magalhães Pinto, em Minas Gerais, e Carlos Lacerda, na Guanabara, não conseguiram eleger os seus sucessores. As vitórias de Israel Pinheiro da Silva (PSD), em Minas Gerais, e Francisco Negrão de Lima (PSD), na Guanabara, representaram uma derrota ao regime, desencadeando uma crise político-militar. Insuflados por Carlos Lacerda e Magalhães Pinto, a "linha dura" exigia que os governadores eleitos em Minas Gerais e na Guanabara não tomassem posse, pois não admitia a eleição de candidatos que a "revolução" deveria ter punido ${ }^{28}$. Embora os candidatos vitoriosos não fossem, de maneira alguma, elementos "perigosos" da oposição - pelo contrário, iriam facilmente adaptar-se e colaborar com o governo Castelo Branco -, eram vistos pelos militares radicais como pessoas ligadas ao ex-presidente Juscelino Kubitschek, cassado pelo $\mathrm{AI}-1^{29}$.

Entretanto, o marechal-presidente Castelo Branco garantiu a posse dos governadores eleitos, o que gerou um movimento - na noite de 5 de outubro, na Vila Militar, no Rio de Janeiro - para depor Castelo Branco. Porém, a intervenção do general Costa e Silva (ministro da Guerra), que conseguiu um acordo com os militares rebeldes da "linha dura", impediu a rebelião militar e o fortaleceu politicamente no processo sucessório à presidência da República $^{30}$.

Superada a ameaça de rebelião militar, Castelo Branco decretou, no dia 27 de outubro de 1965, o Ato Institucional n 2 (AI-2), que estabeleceu eleição indireta para a presidência da República, extinguiu os partidos políticos existentes e aumentou significativamente o poder Executivo, que poderia cassar mandatos, suspender direitos políticos e decretar o recesso do Congresso $^{31}$.

Alguns historiadores consideram o AI-2 uma vitória da "linha dura". No entanto, para João Roberto Martins Filho, o Ato foi um redirecionamento e não uma derrota frontal do

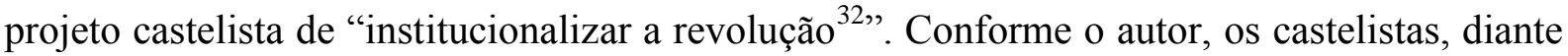


da inevitabilidade de um novo ato institucional, mostraram-se capazes de incluir uma série de medidas que vinham sendo discutidas, em certos círculos do governo, há bastante tempo ${ }^{33}$.

O AI-2 também implantou uma reforma partidária, pois Castelo Branco acreditava que não contava com uma base sólida e estável no Congresso. Como a ditadura pretendia implantar um simulacro de democracia ao regime, não cairia bem adotar o modelo de partido único, associado às ditaduras monopartidárias. Assim, a alternativa adotada foi a criação de um novo sistema partidário, com dois ou, no máximo, três partidos políticos. No entanto, as exigências legais, na prática, possibilitaram a criação de apenas dois partidos, dando início ao bipartidarismo, cujo objetivo era a criação de um forte partido de apoio parlamentar ao governo e de um fraco partido oposicionista. Desse modo, foram gestados a Aliança Renovadora Nacional (ARENA) e o Movimento Democrático Brasileiro (MDB).

A organização do grande partido governista revelou-se uma difícil tarefa, uma vez que era necessário aglutinar em uma mesma organização partidária grupos heterogêneos de diferentes tendências políticas, oriundos dos extintos partidos, cujos interesses e rivalidades, sobretudo em nível estadual e local, eram difíceis de conciliar. Assim, diante das dificuldades apresentadas, criou-se o sistema das sublegendas - por meio do Ato Complementar 26 (AC26), de 29 de novembro de 1965 -, que constituía em um mecanismo que comportava a formação de grupos adversários dentro de um mesmo partido para concorrer às eleições majoritárias, isto é, cada partido poderia apresentar até três candidatos, permitindo que as lideranças dos antigos partidos pudessem disputar os votos dos eleitores nas eleições para as prefeituras do interior ${ }^{34}$ e para o Senado ${ }^{35}$. No sistema das sublegendas, os votos dados às sublegendas partidárias eram somados e a totalidade dos votos era atribuída ao candidato mais votado do partido.

No que tange ao partido oposicionista, organizá-lo não foi também uma tarefa fácil, uma vez que a oposição encontrava-se fragilizada após as séries de cassações empreendidas pelo AI-1. Assim, os oposicionistas formavam um pequeno e heterogêneo grupo. Apesar das divergências político-ideológicas, o único ponto consensual, responsável pela união efetiva dos parlamentares oposicionistas em torno do MDB, foi a defesa do Estado de direito, ou seja, o retorno da democracia, que tornou-se a principal bandeira defendida pelo partido durante toda a sua existência ${ }^{36}$.

No final de 1965 e início de 1966, ARENA e MDB procuraram se organizar a partir da filiação dos deputados federais e senadores, conforme a exigência do Ato Complementar 4 (AC-4, decretado em 20 de novembro de 1965), que estabeleceu as normas para a criação dos 
novos grupos políticos. Dessa forma, a ARENA contou com a adesão de 257 (62,8\%) deputados federais e $44(67,7 \%)$ senadores, enquanto ingressaram no MDB 149 (36,5\%) deputados federais e $21(32,3 \%)$ senadores ${ }^{37}$. Portanto, a ARENA praticamente controlava dois terços do Congresso, correspondendo aos objetivos da ditadura.

Durante o período de novembro de 1965 a março de 1966, ambos os partidos procuraram organizar os seus diretórios nacionais e estaduais e os programas e estatutos partidários. Em 24 de março de 1966, ARENA e MDB foram reconhecidos pelo Tribunal Superior Eleitoral (TSE). O MDB foi oficialmente instalado no dia 30 de março de 1966, enquanto a ARENA foi oficialmente instalada no dia seguinte, 31 de março, no aniversário de dois anos da "Revolução de $1964^{38, " . ~}$

\section{As eleições indiretas e parlamentares de 1966: casuísmos e o jogo de cartas marcadas}

Desde a decretação do AI-2, em 27 de outubro de 1965, já estava definido que a sucessão presidencial seria indireta e o general Arthur da Costa e Silva, que ambicionava a presidência desde o golpe que derrubou João Goulart e articulava a sua candidatura por meio do Ministério da Guerra, fortaleceu-se politicamente após a sua atuação na crise políticomilitar de outubro de 1965, uma vez que obteve êxito em se apresentar como candidato da unidade militar ${ }^{39}$. Embora o nome de Costa e Silva contrariasse as perspectivas do grupo castelista para a sucessão presidencial, o marechal-presidente Castelo Branco se viu obrigado a aceitar a candidatura do ministro da Guerra, que foi homologada pela ARENA.

Com a decretação do AI-3, em 5 de fevereiro de 1966, também foi estabelecida a eleição indireta para os governos estaduais. Assim, em 1966 ocorreriam eleições indiretas para governadores de 12 estados $^{40}$. A vitória dos candidatos governistas era certa, exceto no Rio Grande do Sul, onde o MDB e um grupo de deputados dissidentes da ARENA lançaram a candidatura do jurista e professor Rui Cirne Lima ao governo estadual.

No entanto, em julho de 1966, o marechal-presidente Castelo Branco, para impedir a vitória da oposição, utilizou o AI-2 e cassou os mandatos de sete deputados estaduais do Rio Grande do Sul, além de decretar o Ato Complementar 16 (AC-16, de 19 de julho de 1966), implantando a fidelidade partidária - que considerava nulo o voto de todo parlamentar que, nas eleições indiretas, votasse em um candidato de outro partido.

Em consequência às medidas casuísticas da ditadura, o MDB, em protesto, decidiu que não participaria das eleições indiretas aos governos estaduais e à presidência da República. Dessa forma, no dia 3 de setembro de 1966, a ARENA elegeu os governadores dos 12 
estados. No que tange à eleição presidencial indireta, realizada em 3 de outubro de 1966, no Congresso Nacional, Costa e Silva foi eleito, enquanto o MDB não compareceu em sinal de protesto $^{41}$.

Após a eleição presidencial indireta de outubro, o governo Castelo Branco enfrentou uma crise política com o Congresso, após as cassações de seis deputados federais oposicionistas, no dia 12 de outubro. No entanto, Adauto Lúcio Cardoso, presidente da Câmara dos Deputados e a quem caberia colocar em prática a decisão do governo, num gesto de rebeldia, determinou que os seis deputados cassados permanecessem no Congresso, inclusive permitindo que quatro deles discursassem e criticassem duramente Castelo Branco na sessão do dia 17 de outubro. Embora fosse próximo do marechal-presidente, Adauto Cardoso não concordou com a atitude de Castelo Branco, que havia lhe assegurado que não ocorreriam mais cassações, defendendo que as cassações deveriam ser votadas em plenário, mediante votação secreta. Tal posição foi apoiada por Auro de Moura Andrade, presidente do Senado. "Esse foi o primeiro episódio no qual se levantaram argumentos sobre a inviolabilidade de mandatos parlamentares, a independência e a autonomia do Legislativo"42.

Em resposta, no dia 20 de outubro, Castelo Branco decretou, por meio do AC-23, o recesso do Congresso até o dia 22 de novembro. Dessa forma, o Congresso permaneceu fechado por 32 dias. E foi nesse clima de crise política que ocorreram as eleições parlamentares, em 15 de novembro. Nesse pleito, a ARENA obteve um excelente resultado eleitoral, ampliando ainda mais o número de cadeiras em relação ao MDB: no Senado, a ARENA elegeu 18 senadores contra quatro do MDB; na Câmara dos Deputados, a ARENA elegeu $277(67,7 \%)$ deputados contra $132(32,2 \%)$ do MDB $^{43}$.

Nos últimos meses de 1966, o marechal-presidente Castelo Branco acelerou o seu projeto de "institucionalização da Revolução" e procurou substituir a Constituição de 1946 por uma nova Carta, que vinha sendo arquitetada pelo governo desde abril de 1966. Procurando manter a aparência de "legalista", Castelo Branco manobrou para evitar que a nova Constituição ficasse com a imagem de outorgada. Assim, decretou o AI-4, em 7 de dezembro de 1966, convocando o Congresso Nacional para se reunir extraordinariamente, entre 12 de dezembro de 1966 a 24 de janeiro de 1967, para discutir e votar o projeto da nova Carta.

Portanto, o governo praticamente impôs uma nova Constituição, "promulgada" no dia 24 de janeiro de $1967^{44}$, que incorporou os Atos Institucionais, estabelecendo eleições indiretas para a presidência da República e para os governos estaduais, além de consagrar o 
fortalecimento do Executivo, facultando ao presidente da República a possibilidade de propor emendas constitucionais. Em seguida, Castelo Branco sancionou, em fevereiro de 1967, uma Lei de Imprensa restritiva e, em março de 1967, uma nova Lei de Segurança Nacional que instituiu a noção de "guerra interna" contra o "inimigo interno" - chamado genericamente de "subversivo" -, adotando sistematicamente uma política repressiva baseada no Terrorismo de Estado (TDE). Desse modo, o marechal-presidente Castelo Branco foi fundamental para a construção da ordem jurídico-institucional autoritária ${ }^{45}$.

Por outro lado, Castelo Branco terminou o seu mandato bastante impopular ${ }^{46}$, sofrendo críticas de setores militares e civis e assistindo ao crescimento da oposição, que articulou a criação da Frente Ampla - que aglutinou Carlos Lacerda ${ }^{47}$ e os ex-presidentes (cassados pelo AI-1) Juscelino Kubitschek e João Goulart -, oficialmente criada em outubro de $1966^{48}$.

\section{O AI-5}

A partir do final de 1967, capitaneado pela Frente Ampla, a oposição ao governo Costa e Silva começou a ganhar volume. Porém, a proibição da Frente Ampla, em 5 de abril de 1968, não estancou o crescente movimento oposicionista à ditadura, caracterizado pela intensificação do movimento estudantil, pela eclosão de movimentos grevistas e pelas críticas de setores da Igreja católica e de parlamentares emedebistas. Dessa forma, desde o final de março de 1968, o país passou a viver sob a ameaça da decretação do Estado de sítio e do fechamento do regime.

No final do ano, após a derrota da ditadura no Congresso no caso Márcio Moreira Alves $^{49}$, o general-presidente Arthur da Costa e Silva convocou, no dia 13 de dezembro, o Conselho de Segurança Nacional. A reunião resultou a edição do Ato Institucional $n^{\circ} 5$ (AI5), de autoria do ministro da Justiça, Luís Antônio da Gama e Silva. O principal argumento para a promulgação do Ato foi a "subversão social e política" (isto é, o crescente movimento de oposição ao regime) que ameaçava a "revolução". A derrota do governo no caso Márcio Moreira Alves foi apenas o pretexto que faltava para o aprofundamento da ditadura.

De acordo com Marcos Napolitano, a promulgação do AI-5 deve-se não exclusivamente à pressão exercida pelos militares da "linha dura", mas principalmente pela leitura convergente que os vários grupos militares fizeram das mobilizações sociais, estudantis e da crise politica de 1968, interpretadas como "perigosos elementos de desestabilização da "revolução",50, "comprometida por processos subversivos e de guerra revolucionária" em marcha ${ }^{51}$. Em outras palavras, o AI-5 foi mais o produto da união do que 
da desunião militar ${ }^{52}$, visando a revigorar a "revolução" contra uma suposta ameaça de "insurreição subversiva e comunista", em uma "ofensiva imaginada como uma espécie de retorno às fontes originais de 1964, tendo em vista também unificar as Forças Armadas na defesa do regime ${ }^{53}$,

O AI-5 acentuou ainda mais o caráter ditatorial do regime que havia iniciado em 1964, dando amplos poderes discricionários ao presidente da República por tempo ilimitado. Em outras palavras, a partir do AI-5, o presidente da República passou a gozar de amplos poderes para legislar por decreto, cassar mandatos eletivos, suspender direitos políticos, demitir ou aposentar juízes e outros funcionários públicos, decretar o recesso do Congresso Nacional, das Assembleias Legislativas e das Câmaras de Vereadores por Ato Complementar, entre outras medidas autoritárias, como, por exemplo, a suspensão do habeas corpus em crimes políticos e o julgamento de crimes políticos em tribunais militares sem direito a recurso. Composto por 12 artigos, o AI-5 representou o aprofundamento da ditadura e a amplificação do recurso à repressão (que já vinha sendo praticada e estruturada desde 1964) a qualquer movimento social e oposicionista, uma vez que se tornou um instrumento punitivo a ser utilizado a qualquer momento e contra quem quer que fosse considerado inimigo do regime.

Ademais, Rodrigo Patto Sá Motta ressalta que o AI-5 também visava a enquadrar os segmentos dissidentes da elite, que se mostravam rebeldes ao poder militar, permitindo a cassação de parlamentares da ARENA, aposentar servidores públicos incômodos para o governo, como juízes que impediam a "justiça revolucionária" de agir livremente, ou professores universitários acusados de estimular a rebeldia estudantil ${ }^{54}$.

No final da noite do dia 13 de dezembro, o ministro Gama e Silva anunciou, em cadeia de rádio e televisão, a decretação do AI-5 e do Ato Complementar 38 (AC-38), que decretou o recesso do Congresso por tempo indeterminado ${ }^{55}$. No dia 20 de dezembro de 1968, a ditadura decretou o AC-39, que regulamentava as cassações de mandatos, aposentadorias, demissões e suspensão dos direitos políticos por 10 anos. Assim, no dia 30 de dezembro teve início à série de cassações, que atingiram Carlos Lacerda e 11 deputados federais que foram vinculados a Frente Ampla ${ }^{56}$. No dia 31 de dezembro de 1968, Costa e Silva divulgou uma Mensagem ao povo brasileiro, responsabilizando, em grande parte, os parlamentares da ARENA pela decretação do AI-5, uma vez que o partido não seguia à sua orientação no Congresso ${ }^{57}$.

No dia 7 de fevereiro de 1969, por meio do AC-47, a ditadura decretou o recesso das Assembleias Legislativas de São Paulo, do Rio de Janeiro, da Guanabara, de Pernambuco e de Sergipe. Posteriormente, no dia 27 de fevereiro de 1969, por meio do AC-49, foi decretado o 
recesso das Assembleias de Goiás e do Pará. Essas sete Assembleias Legislativas ficaram em recesso por mais de um ano.

Em 1969, as cassações prosseguiram. Até o final do ano foram cassados 98 deputados federais e suplentes (67 do MDB e 31 da ARENA) e cinco senadores do MDB (Cf. Azevedo e Rabat, 2012). Portanto, o principal alvo foi o MDB, cujas cassações reduziram em cerca de 50\% a sua bancada na Câmara dos Deputados. Convém lembrar que o AI-5 também cassou inúmeros deputados estaduais, prefeitos e vereadores.

Além das cassações de políticos em nível nacional, estadual e municipal, com o AI-5 ocorreu uma série de aposentadorias compulsórias ou demissões de cerca de 500 profissionais, como juízes, embaixadores, militares, professores universitários, jornalistas, funcionários públicos, entre outros, que perderam os seus empregos e os seus direitos políticos. Ademais, a perseguição política a todos os que eram considerados inimigos da "Revolução" se exacerbou, com a amplificação do Terrorismo de Estado, que fez uso sistemático da tortura e do assassinato.

\section{A reabertura do Congresso Nacional e a eleição indireta de Emílio Médici}

No final de agosto de 1969, o estado de saúde do general-presidente Costa e Silva se agravou em decorrência de uma trombose, que resultou em um derrame ${ }^{58}$. Impossibilitado de governar, no dia 31 de agosto, Costa e Silva foi substituído temporariamente por uma junta militar formada pelos três ministros militares - o general Aurélio Lyra Tavares (ministro do Exército), o almirante Augusto Rademaker (ministro da Marinha) e o brigadeiro Márcio de Souza e Mello (ministro da Aeronáutica) -, que por meio de um Ato Institucional (o AI-12, de

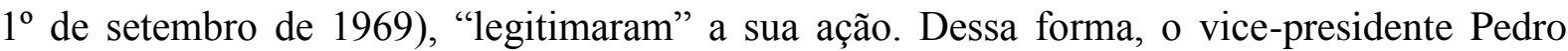
Aleixo - considerado suspeito por ter sido o único membro do Conselho de Segurança Nacional a votar contra a decretação do AI-5 - foi impedido pelos militares de assumir a presidência, sendo definitivamente alijado do processo sucessório ${ }^{59}$ (Skidmore, 1988).

Com as disputas pela sucessão presidencial ameaçando dividir as Forças Armadas, o general Emílio Garrastazu Médici foi escolhido para a sucessão de Costa e Silva. Conforme Thomas Skidmore, Médici foi escolhido não porque os militares achassem que ele tinha a visão ou os conhecimentos de que um presidente precisava, mas porque era o único general de quatro estrelas que podia impedir o aprofundamento da divisão no Exército ${ }^{60}$. Assim, no início de outubro, Médici foi oficialmente anunciado como o futuro general-presidente e é decretado o AI-16 (de 14 de outubro de 1969), que declarava a vacância da presidência (em 
virtude do estado de saúde de Costa e Silva), marcando para o dia 25 de outubro as eleições indiretas no Congresso Nacional.

Dessa forma, após mais de dez meses em recesso, o Congresso voltou a funcionar em 22 de outubro de 1969 para, no dia 25 de outubro, eleger indiretamente o general Emílio Médici presidente da República por 293 votos favoráveis contra 76 abstenções (do MDB) ${ }^{61}$. Contudo, convém lembrar que o Congresso Nacional retornou às suas atividades significativamente mutilado pelo AI-5, uma vez que foram cassados 98 deputados federais e suplentes (67 do MDB e 31 da ARENA) e cinco senadores do MDB. Assim, a ARENA retornou ao Congresso adotando uma postura bastante prudente e totalmente submissa, uma vez que Costa e Silva havia responsabilizado grande parte dos parlamentares arenistas pela decretação do AI-5. Embora tal situação desagradasse alguns arenistas, o partido passou a limitar-se apenas a homologar as decisões do Alto Comando das Forças Armadas ${ }^{62}$.

O MDB, por sua vez, no período entre 1969-1970, também adotou uma postura política demasiadamente moderada e "bem comportada". Dessa forma, a postura submissa adotada pelo MDB em 1969-1970 praticamente não o diferenciava da ARENA, pois ambos eram obedientes e dóceis à ditadura. Em virtude disso, nessa época passou a circular uma anedota irônica, na qual o MDB seria o partido do "sim", enquanto a ARENA seria o partido do "sim senhor", isto é, os dois partidos se dobravam à vontade do poder, mas a ARENA o fazia com mais servilismo e menos pudor ${ }^{63}$.

Empossado no dia 30 de outubro de 1969, o general-presidente Emílio Médici deu continuidade à política econômica que resultaria em uma breve fase de controle inflacionário e de crescimento econômico, conhecido como "milagre brasileiro ${ }^{64 "}$ (1968-1973), que foi amplamente capitalizado pela ditadura, que, utilizando de uma intensa propaganda ufanista, angariou elevados índices de popularidade ${ }^{65}$.

Alinhado à "linha dura”, o governo do general-presidente Emílio Médici correspondeu ao período de auge da repressão política, no qual a máquina repressiva, montada nos anos anteriores e baseada no tripé vigilância/censura/repressão, seria aperfeiçoada e funcionaria a todo vapor. As bases teóricas que nortearam a montagem desta máquina repressiva foram a Doutrina de Segurança Nacional e o conceito de guerra interna ou guerra revolucionária, de influência francesa ${ }^{66}$.

A vigilância era um aspecto estratégico para o regime. Sua função central era produzir informações sobre pessoas, movimentos sociais, instituições e grupos políticos legais ou ilegais, evitando surpresas para o governo. Informações que poderiam, no futuro, produzir a 
culpabilidade dos vigiados. O eixo do sistema de informações era o Serviço Nacional de Informações (SNI), criado em junho de 1964. Idealizado pelo general Golbery do Couto e Silva, a função do SNI era produzir informações sobre pessoas, movimentos sociais, instituições e grupos políticos legais ou clandestinos, evitando surpresas para o governo ${ }^{67}$.

No entanto, o SNI era uma estrutura informativa, mas não operativa no combate à "subversão". Já os serviços de inteligência militar ${ }^{68}$, assim como também os DOPS (Delegacia de Ordem Política e Social) estaduais, eram informativos e operativos. Desse modo, até o final dos anos 1960, os serviços de inteligência militar - sob a responsabilidade dos respectivos ministros militares - e os DOPS estaduais eram os principais responsáveis pelas operações de repressão política, não havendo um sistema nacional, militarizado e integrado de repressão. Entretanto, o crescimento da luta armada contra a ditadura, a partir de 1968, gerou a criação do DOI-CODI (Destacamento de Operações e Informações - Centro de Operações de Defesa Interna) em 1970. De natureza militar, o sistema DOI-CODI ${ }^{69}$ estava sob o controle direto dos comandos de cada Exército ou região militar e poderia se comunicar com os serviços de inteligência de cada força, que continuavam existentes e atuantes ${ }^{70}$.

A partir do sistema DOI-CODI, a máquina repressiva esmagou a luta $\operatorname{armada}^{71}$ e as ações civis de oposição ao regime. Além do uso brutal da tortura - que desprezou qualquer limite jurídico e humanitário, além da própria ética militar, que prega o tratamento digno aos prisioneiros -, a ditadura militar brasileira, sobretudo a partir de 1971, inventou o “desaparecido político": oficialmente, nem preso, nem morto ${ }^{72}$.

No que tange à censura, a ditadura militar não a inventou, mas a ampliou. À existente censura moral - que visava a coibir "atentados à moral e aos bons costumes" - foi implementada a censura política para "impedir a divulgação de notícias ou comentários contrários ao regime e às instituições". Desse modo, não havia uma, mas duas censuras, que enquadraram jornais, revistas, livros, rádio, televisão, cinema, teatro, música e as demais atividades artísticas e culturais ${ }^{73}$.

\section{As eleições indiretas e parlamentares de 1970 e 1974}

Em 1970, o general-presidente Emílio Médici decidiu intervir nas sucessões estaduais, uma vez que os governos estaduais eram importantes posições estratégicas no sistema político, escolhendo os governadores estaduais, cujas candidaturas foram homologadas pelos diretórios estaduais da ARENA. No dia 3 de outubro de 1970, os governadores escolhidos por Médici foram eleitos indiretamente pelas Assembleias Legislativas, recebendo os votos da 
ARENA - que detinha a maioria dos parlamentares nos legislativos estaduais -, enquanto o MDB, em protesto, optou pela abstenção e não compactuar com o jogo de cartas marcadas.

No mês seguinte, em 15 de novembro de 1970, ocorreram as eleições parlamentares, que foram amplamente favoráveis à ARENA, que elegeu 41 senadores e 223 (71,9\%) deputados federais, enquanto o MDB elegeu apenas cinco senadores e $87(28,1 \%)$ deputados federais $^{74}$. De acordo com a observação de Maria Kinzo, um dos fatores que contribuíram para a derrota do MDB em 1970 foi o seu comportamento moderado, que contribuiu para o aumento do número de votos brancos e nulos (que chegaram a $30 \%$ na eleição para a Câmara dos Deputados, superando os $21 \%$ das eleições de 1966) ${ }^{75}$.

Segundo Rodrigo Patto Sá Motta, a conduta conformista e submissa adotada pelo MDB contribuiu para que setores da sociedade, simpáticos às posturas oposicionistas, preferissem anular os seus votos a dá-lo aos MDB, pois, naquele contexto, muitos achavam que apoiar o MDB era prestar um serviço aos militares. Portanto, os votos brancos e nulos eram, ao mesmo tempo, um protesto contra a ilegitimidade do sistema e uma demonstração de falta de confiança no MDB, considerada tanto quanto a ARENA um produto do autoritarismo ${ }^{76}$.

Ademais, Maria Kinzo também aponta outros fatores que ajudam a compreender o fracasso do MDB nas eleições de 1970: a) o controle exercido pelo governo sobre o processo eleitoral por meio da censura e da repressão policial; b) a intensa propaganda governamental, que se utilizava das altas taxas de crescimento econômico geradas pelo chamado "milagre brasileiro" $" 77$.

Em suma, para o MDB a derrota eleitoral de 1970 foi maior do que a derrota de 1966, gerando um período de incertezas e de crise interna dentro do partido. Após as eleições, Oscar Passos, que não se reelegeu para o Senado, mostrou-se disposto a renunciar à presidência nacional do MDB, convocando para fevereiro de 1971 uma convenção nacional para eleger a nova Executiva nacional. No referido encontro, o deputado federal Ulysses Guimarães (MDB/SP) foi eleito o novo presidente nacional do partido.

Em fevereiro de 1971, além da ascensão de Ulysses Guimarães à presidência do MDB, o deputado Oscar Pedroso Horta (MDB/SP) foi indicado como líder da oposição na Câmara dos Deputados. Foi em torno da sua liderança que se articulou um grupo de parlamentares que adotaram uma postura oposicionista mais combativa, sendo conhecidos como "autênticos", composto basicamente por deputados de primeiro mandato, representando aproximadamente $25 \%$ dos parlamentares emedebistas ${ }^{78}$. 
Os "autênticos", que discordavam da orientação moderada da direção do partido, caracterizavam-se por ser um pequeno grupo dentro do MDB que pretendia fazer uma oposição real, "autêntica", à ditadura militar e não apenas uma oposição consentida. Na Câmara dos Deputados, os "autênticos" adotaram uma atuação combativa e os seus discursos ganharam destaque nas tribunas, caracterizadas pelo tripé democracia, nacionalismo e reivindicações sociais. De acordo com Rodrigo Patto Sá Motta, “parte dos autênticos não tinha perfil de esquerda, eram liberais ou democratas que assumiram atitude de oposição radical ao autoritarismo. A marca principal do grupo não era a afinidade ideológica, mas a atitude aguerrida e corajosa num contexto de extrema repressão ${ }^{79}$ ". Os "autênticos" também se notabilizaram pela defesa dos direitos humanos, denunciando casos de prisões arbitrárias, torturas, desaparecimentos e mortes de opositores da ditadura ${ }^{80}$.

Em junho de 1973, o general-presidente Emílio Médici anunciou o general Ernesto Geisel - irmão de Orlando Geisel, que, na condição de ministro do Exército, controlou eventuais dissensões na oficialidade - como o seu sucessor ${ }^{81}$. Dessa forma, o nome de Ernesto Geisel obteve o consenso militar e a sua indicação à sucessão presidencial ocorreu de forma tranquila, sem os agudos conflitos que caracterizaram as sucessões anteriores.

Por sua vez, o MDB, pela primeira vez, optou em lançar um candidato à sucessão presidencial. Mesmo ciente de que não teria nenhuma chance de vitória, o objetivo do partido era desenvolver, em âmbito nacional, uma campanha para denunciar a farsa das eleições indiretas à presidência da República. Assim, o MDB lançou a candidatura de Ulysses Guimarães, que denominou a campanha de "anticandidatura" à presidência ${ }^{82}$.

Entretanto, como era previsível, no dia 15 de janeiro de 1974, o general Ernesto Geisel foi eleito indiretamente presidente da República, sendo empossado no dia 15 de março de 1974. No que tange à composição do governo, Ernesto Geisel nomeou um ministério majoritariamente vinculado ao grupo "castelista-geiselista" (também chamado de "Sorbonne militar"), com destaque para o general Golbery do Couto e Silva para a Casa Civil da Presidência.

Alguns meses após assumir a presidência, o general-presidente Geisel anunciou o projeto de distensão política lento, gradual e seguro que visava à institucionalização ou constitucionalização das leis de exceção, isto é, a saída da excepcionalidade com a integração dos atos discricionários na Constituição, e não exatamente a redemocratização do país ${ }^{83}$. Assim, o projeto de distensão política, lento, gradual e seguro pretendia descomprimir paulatinamente o regime por meio de uma limitada liberalização, porém sem abrir mão de 
"mecanismos de segurança", ou seja, de instrumentos de repressão, que deveriam ser institucionalizados, comportando, assim, garantias básicas de uma passagem negociada, em um futuro incerto, para um governo civil identificado com as "doutrinas revolucionárias" Contudo, paralelamente ao projeto de distensão política, o general-presidente Ernesto Geisel precisou lidar com o esgotamento do "milagre brasileiro", acompanhado por uma grave crise econômica e o crescimento significativo da inflação e da dívida externa.

No que tange às sucessões estaduais de 1974, Geisel, assim como ocorreu em 1970 com Médici, também escolheu os governadores dos estados, que foram eleitos indiretamente pelas Assembleias Legislativas no dia 3 de outubro de 1974, recebendo os votos da ARENA, enquanto o MDB, mais uma vez, optou pela abstenção.

Nas eleições parlamentares de 15 de novembro de 1974, o MDB dedicou atenção especial à organização da sua campanha eleitoral, sobretudo no rádio e na televisão, e explorou o agravamento da situação socioeconômica nacional e o aumento vertiginoso da inflação em $1974^{85}$. Desse modo, o MDB obteve em 1974, pela primeira vez, um excelente desempenho eleitoral, elegendo 16 senadores contra apenas seis da ARENA ${ }^{86}$. Na Câmara dos Deputados, o MDB quase duplicou a sua bancada, elegendo 160 deputados federais, enquanto a ARENA elegeu 204 deputados ${ }^{87}$. Ademais, o MDB elegeu a maioria dos deputados estaduais em seis Assembleias ${ }^{88}$.

De acordo com Rodrigo Patto Sá Motta, alguns fatores explicam os resultados eleitorais de 1974: a) a agressividade do MDB, que adotou posturas críticas mais contundentes; b) o fim do otimismo em relação ao crescimento econômico em virtude do esgotamento do "milagre econômico"; c) a eficiência do MDB na campanha, utilizando com inteligência a televisão, que, pela primeira vez, teve um papel importante nas disputas eleitorais; d) o fato das eleições terem sido relativamente abertas, com menor índice de repressão desde $1965^{89}$.

Portanto, a vitória eleitoral do MDB em 1974 (denominada pelos oposicionistas de "ressaca cívica nacional") representou um duro golpe para o governo e um aviso da insatisfação social com a inflação e a carestia. A ditadura militar entraria em crise, desgastada pelo agravamento da crise econômica e pelas manifestações de setores da sociedade civil e da Igreja católica pelo retorno à democracia. 


\section{A oposição militar ao governo Geisel e a "segunda linha dura"}

Após a vitória eleitoral do MDB em 1974, o projeto de distensão política passou a ser contestado pelos militares da "linha dura". De acordo com Maud Chirio, tratava-se de uma "segunda linha dura" ou "direita radical" dos anos 1970, que se articulava nas comunidades de informações, nos DOI-CODIs e no interior do próprio Ministério do Exército, com o general Sylvio Frota, que se recusavam a sair da "excepcionalidade revolucionária", alegando a eterna "ameaça subversiva". Compostos de uma nova geração de oficiais contestadores, cuja maioria atuava no aparelho repressivo, essa "segunda linha dura" lutava para conservar sua posição dentro do Estado policial ${ }^{90}$.

Em suma, a "segunda linha dura" defendia a preservação do aparelho repressivo e da estrutura ditatorial, uma vez que a guerra contra o comunismo - que justificou a sua criação ainda não havia terminado. Aliás, para a "direita radical" a ameaça subversiva era eterna". Desse modo, por meio de panfletos virulentos, a "segunda linha dura" demonstrava a sua insatisfação com o projeto de distensão política de Geisel-Golbery, interpretando a sua limitada liberalização como uma fraqueza do governo que possibilitaria o retorno da "subversão comunista", infiltrada no MDB. A autoria desses panfletos era do Grupo Secreto $^{92}$.

No entanto, a "segunda linha dura" era controlada pelo general-presidente Ernesto Geisel, que contemporizava a repressão política e os numerosos casos de torturas, assassinatos e desaparecimentos de oposicionistas que continuaram a ocorrer durante o seu governo ${ }^{93}$. Afinal, para Geisel o "porão" ainda era útil, desde que não atrapalhasse o projeto de institucionalização do regime e não desafiasse abertamente a sua autoridade ${ }^{94}$. Em suma, havia um acordo velado no qual a cúpula militar era conivente com o "porão", permitindo que os órgãos de repressão fizessem o "trabalho sujo" sem o seu envolvimento, ao mesmo tempo em que assegurava a impunidade aos perpetradores. Desse modo, a justificativa era que as torturas e mortes decorriam dos "excessos" de alguns poucos militares, escapando do controle dos oficiais-generais ${ }^{95}$.

Com a esquerda armada aniquilada, a repressão, sobretudo a partir de 1975, voltou-se contra o PCB, que, apesar de não ter aderido à luta armada, foi dizimado, acusado pelo governo de ter tido influência na vitória da oposição nas eleições de 1974. Contudo, alguns casos de torturas, desaparecimentos de oposicionistas e assassinatos (como do jornalista Vladimir Herzog, morto em outubro de 1975 no DOI-CODI de São Paulo) passaram a ter ampla repercussão na sociedade civil e na opinião pública ${ }^{96}$, gerando reações da Ordem dos 
Advogados do Brasil (OAB), da Associação Brasileira de Imprensa (ABI) e de setores da Igreja católica.

Em janeiro de 1976, o assassinato do sindicalista Manuel Fiel Filho no DOI-CODI de São Paulo levou Geisel a substituir o general Ednardo D’Ávila Mello do comando do II Exército, desagradando ao general Sylvio Frota, ministro do Exército e considerado porta-voz da "linha dura" 97 . Segundo Maud Chirio, a substituição do comando do II Exército sinalizava que o general-presidente Ernesto Geisel decidiu intervir e controlar o aparelho repressivo ${ }^{98}$. Entretanto, a tentativa de Geisel de controlar o "porão" gerou a reação da "segunda linha dura", que considerava o general-presidente, juntamente com o general Golbery do Couto e Silva, "traidores da Revolução". Dessa forma, a "direita radical", por meio do Grupo Secreto, voltou a distribuir violentos panfletos contra Geisel e Golbery, difundindo a absurda teoria de que ambos planejavam a adesão ao comunismo ${ }^{99}$.

Influenciados pela paranoia anticomunista, o Grupo Secreto não seria o único a promover agitações de extrema-direita, surgindo o grupo paramilitar Aliança Anticomunista Brasileira (AAB), apontada como responsável pelas bombas plantadas no dia 19 de agosto de 1976, no Rio de Janeiro, nas sedes da Ordem dos Advogados do Brasil (OAB) e da Associação Brasileira de Imprensa $(\mathrm{ABI})$ - onde as bombas explodiram sem ocasionar vítimas. Nos meses seguintes, a AAB praticaria novos atentados a bombas e atos de violência contra pessoas, associações e órgãos de imprensa ${ }^{100}$ considerados pelos extremistas como “inimigos da Revolução" e "comunistas"

\section{A Lei Falcão e o "Pacote de Abril": novos casuísmos da ditadura}

Após a derrota eleitoral de 1974, o general-presidente Ernesto Geisel passou a priorizar a vitória da ARENA nas eleições municipais de 1976. Dessa forma, visando a enfraquecer o MDB, a ditadura militar arquitetou uma série de mudanças nas regras eleitorais, que ficaram conhecidas como Lei Falcão (em referência ao ministro da Justiça, Armando Falcão, seu idealizador). Promulgada no início de julho de 1976, a Lei Falcão (Lei 6.339/76) proibia os candidatos de realizar qualquer tipo de pronunciamento no rádio e na televisão. Desse modo, os partidos poderiam apenas divulgar, nas campanhas eleitorais, os nome, os números e as fotos dos candidatos, acompanhado da leitura dos seus currículos, esvaziando a campanha eleitoral no rádio e na televisão, transformando-a em um modorrento e inócuo desfile de currículos e fotografias ${ }^{102}$. Portanto, a Lei Falcão foi mais um casuísmo da ditadura, que modificou as regras do jogo eleitoral para silenciar o MDB, que, em 1974, obteve êxito 
na sua campanha política denunciando a inflação, o arrocho salarial e o agravamento da situação socioeconômica do país.

A partir de 1976, o general-presidente Ernesto Geisel utilizou o AI-5 para enquadrar o MDB, cassando os mandatos de deputados emedebistas ${ }^{103}$. A crise política tornou-se acentuou-se no final do ano, quando o general-presidente Ernesto Geisel enviou ao Congresso um projeto de emenda constitucional para reformar o sistema judiciário. Na verdade, o projeto de reforma do Judiciário foi uma espécie de "balão de ensaio" para avaliar a situação e a receptividade à introdução de outras reformas políticas, que seriam mais tarde enviadas ao Congresso, visando ao projeto de institucionalização do regime ${ }^{104}$.

No entanto, a posição intransigente do general-presidente Ernesto Geisel em não aceitar negociar levou o MDB a posicionar-se contrário ao projeto, impossibilitando, assim, qualquer chance de que o mesmo fosse aprovado. Assim, no dia 30 de março de 1977, o projeto foi votado no Congresso, recebendo 241 votos a favor e 156 contra, não alcançando o quórum de dois terços necessários para ser aprovado ${ }^{105}$.

Em resposta, no dia $1^{\circ}$ de abril de 1977, Geisel usou o AI-5 e emitiu o Ato Complementar 102 (AC-102), decretando o recesso do Congresso, fechado pela terceira vez pela ditadura. Durante o recesso do Congresso, que durou 15 dias, Geisel decretou um conjunto de medidas políticas e econômicas sem o debate parlamentar, como a reforma do Judiciário e seis decretos-leis, que se tornaram conhecidas como "Pacote de Abril". Entre essas medidas estavam: a) derrubada da exigência dos votos de dois terços do Congresso para aprovação dos projetos de emendas constitucionais, que poderiam ser aprovados com a maioria simples, possibilitando que o governo conseguisse aprovar projetos de emendas constitucionais apenas com os votos da ARENA; b) extensão do mandato (de cinco para seis anos) do próximo presidente da República; c) a eleição indireta para um terço das cadeiras no Senado, criando os "senadores biônicos" e garantindo 21 cadeiras senatoriais em 1978 à ARENA $^{106}$.

Em suma, responsabilizando a oposição por não "colaborar", o general-presidente Ernesto Geisel utilizou o AI-5 para fechar o Congresso e impor o "Pacote de Abril", cujas medidas casuísticas visavam a impedir o MDB de eleger cinco governadores e de ter a possibilidade de obter a maioria no Senado a partir de 1978. Apesar dos protestos dos emedebistas, a ditadura explicitava à oposição quais eram os seus limites.

Após a reabertura do Congresso, parlamentares do MDB passaram a defender a promoção de uma grande campanha para denunciar a situação política do país e a mobilizar a 
opinião pública em favor de uma Assembleia Nacional Constituinte ${ }^{107}$. No entanto, a ditadura congelou novamente o MDB, que novamente foi atingindo, em junho de 1977, pelas cassações dos deputados federais do grupo "autêntico" Marcos Tito ${ }^{108}$ (MDB/MG) e José Alencar Furtado ${ }^{109}$ (MDB/PR), líder da oposição na Câmara dos Deputados.

Impactado com as medidas casuísticas do "Pacote de Abril" e com as cassações de Marcos Tito e José Alencar Furtado, o MDB, durante a convenção nacional do partido, realizada em 14 de setembro de 1977, decidiu adotar definitivamente o tema da defesa pela Constituinte, lançando oficialmente a campanha no dia 20 de setembro. No entanto, as chances de êxito da campanha do MDB por uma Constituinte eram nulas, pois o partido foi proibido de realizar na televisão e no rádio qualquer menção à campanha, assim como também de realizar comícios sobre o tema. Desse modo, a campanha da Constituinte duramente criticada pelos arenistas - limitou-se a discursos parlamentares no Congresso e nas Assembleias estaduais e à publicação de um Manual do Constituinte, que explicava em linguagem simples à população o que significava uma Assembleia Nacional Constituinte. Assim, no final de 1977, a campanha pela Constituinte já havia morrido, tornando-se apenas mais um item na agenda do partido $^{110}$.

\section{A crise da ditadura militar, as reformas políticas de 1978 e o fim do AI-5}

Durante o governo Geisel, as manifestações pelo retorno à democracia ganharam volume, sobretudo a partir de 1977, aglutinando um significativo número de políticos liberais, políticos de esquerda, profissionais liberais, setores das classes médias e da Igreja católica, além de intelectuais, professores, estudantes e movimentos sociais numa frente oposicionista que contribuiu para o desgaste da ditadura militar.

Dessa forma, paralelamente ao projeto de distensão política, lento, gradual e seguro (que pretendia descomprimir paulatinamente o regime por meio de uma limitada liberalização), o general-presidente Ernesto Geisel, pressionado por significativos setores da sociedade civil, precisou rever o projeto inicial de distensão política, no qual não pretendia abrir mão do AI-5. Desse modo, após as negociações empreendidas com representantes da sociedade civil, o governo encaminhou ao Congresso, no final de junho de 1978, um projeto de emenda constitucional que propunha, entre outras coisas, a restauração do habeas corpus e a revogação do AI-5.

Embora atendesse algumas das reinvindicações da sociedade civil, o projeto - que foi amplamente criticado pelo MDB - ainda estava longe de introduzir mudanças substanciais no 
regime, pois no lugar do AI-5 seriam introduzidas as "salvaguardas do regime" (denominadas pela oposição de "entulho autoritário"), assegurando ao presidente o uso de mecanismos constitucionais para combater "ações subversivas e de ameaças à segurança nacional"111.

Em 20 e 21 de setembro de 1978, depois de quase três meses de negociações, o projeto de emenda constitucional que tratava das reformas políticas foi aprovado no Congresso. Com as reformas políticas - que passariam a vigorar a partir de $1^{\circ}$ de janeiro de 1979 -, o AI-5 seria extinto após 10 anos de vigência. No entanto, manteve-se uma série de medidas restritivas (as "salvaguardas do regime"), acrescida de uma nova Lei de Segurança Nacional, que passou a vigorar no final de dezembro de 1978. Portanto, com as reformas políticas de 1978, o general-presidente Ernesto Geisel "institucionalizava o regime”, integrando à Constituição as "salvaguardas". Entretanto, os temas do retorno do pluripartidarismo e da anistia política foram deixados para o futuro general-presidente João Batista Figueiredo.

\section{As eleições indiretas e parlamentares de 1978}

Além do crescimento do movimento oposicionista dos diversos setores da sociedade civil pela redemocratização, o general-presidente Ernesto Geisel precisou enfrentar uma crise militar, catalisada pela sucessão presidencial. Para a "segunda linha dura", o projeto de distensão política de Geisel-Golbery era uma "traição aos ideais da Revolução", pois pretendia levar o país ao comunismo. Nesse sentido, as mobilizações da sociedade civil e do clero progressista pelo retorno à democracia, assim como os movimentos sociais, eram interpretadas pela extrema-direita militar como uma prova da progressão do comunismo no país, incentivada pelo governo Geisel. Tal posição era compartilhada pelo general Sylvio Frota, ministro do Exército, que ambicionava a sucessão presidencial e que não escondia suas críticas ao governo Geisel. Defensor dos órgãos de repressão contra as "calúnias da mídia" e contrário ao projeto de distensão política, Sylvio Frota procurava fortalecer-se junto aos quartéis, fazendo campanha no Exército para concorrer à sucessão presidencial como mantenedor do "espírito de 1964", supostamente ameaçado pela "infiltração" de comunistas e subversivos no governo e pelo projeto de distensão ${ }^{112}$.

Em reação, o general-presidente Ernesto Geisel demitiu Sylvio Frota do Ministério do Exército, em 12 de outubro de 1977, e o general Hugo Abreu (Chefe do Gabinete Militar) teve uma importante atuação, neutralizando possíveis reações de unidades militares solidárias a Sylvio Frota. Posteriormente, Ernesto Geisel, no início de janeiro de 1978, anunciou a escolha do general João Batista Figueiredo (então chefe do SNI) para sucedê-lo. 
Insatisfeito com a forma que Geisel tratou a sucessão presidencial - sem consultar o Alto Comando do Exército - e com a escolha do general Figueiredo, o general Hugo Abreu rompeu com o general-presidente e demitiu-se do governo, passando a articular, com os militares insatisfeitos, a candidatura de um líder militar que pudesse concorrer com o general Figueiredo. Desse modo, se aproximou do general Euler Bentes Monteiro, que, embora na reserva, desfrutava de prestígio na corporação militar ${ }^{113}$.

Com as suas ambições frustradas com a indicação de Figueiredo, o senador Magalhães Pinto, que se autoproclamava líder civil da "Revolução de 1964" e candidato da "conciliação nacional", continuou articulando a sua candidatura à presidência. Mesmo após a homologação da candidatura de Figueiredo pela ARENA, Magalhães Pinto manteve a sua candidatura e declarou que pretendia lançar-se como candidato independente, esperando contar com o apoio do MDB e dos dissidentes arenistas, lançando a Frente Nacional de Redemocratização, em maio de 1978. No final de maio, Magalhães Pinto e o general Euler Bentes chegaram a um acordo, no qual se comprometiam a colaborarem juntos no mesmo movimento e ambos assinaram uma nota afirmando que a Frente Nacional de Redemocratização visava a congregar todas as forças políticas comprometidas com o fim do arbítrio e o restabelecimento do Estado de direito democrático no país. Na mesma nota também conclamavam o MDB a integrar a Frente ${ }^{114}$.

No final de junho, o diretório nacional do MDB decidiu pela adesão à Frente e a candidatura do general Euler Bentes fortaleceu-se dentro do partido. Enfraquecido, Magalhães Pinto desistiu da sua candidatura e deixou a Frente em agosto, enquanto o general Euler Bentes filiou-se ao MDB e teve a sua candidatura à presidência homologada pelo partido.

Para garantir a vitória do general Figueiredo na eleição indireta de 15 de outubro de 1978, o governo determinou que a ARENA fizesse uso da lei de fidelidade partidária para obrigar os seus membros a votarem no candidato oficial. Assim, como era previsto, no dia 15 de outubro de 1978, o general João Batista Figueiredo foi eleito indiretamente presidente da República. Um mês antes, em $1^{\circ}$ de setembro de 1978, ocorreram as eleições indiretas para os governos estaduais (escolhidos novamente por Geisel) e dos "senadores biônicos", da qual o MDB novamente absteve-se.

No que tange às eleições parlamentares, realizadas no dia 15 de novembro de 1978 , em nível nacional, a ARENA elegeu 15 senadores contra oito do MDB $^{115}$ e obteve $55 \%$ da representação na Câmara Federal. Além disso, a ARENA também já havia garantido um terço 
do Senado por meio das eleições indiretas (os "senadores biônicos", eleitos em setembro), o que garantiu ao governo a maioria no Congresso ${ }^{116}$.

\section{A reforma político-partidária de 1979, o fim do bipartidarismo e as eleições diretas de 1982}

Ao assumir a presidência da República, em 15 de março de 1979, o general-presidente João Batista Figueiredo deu continuidade ao projeto de distensão política lenta, gradual e segura, que passou a ser chamado de "abertura". No entanto, convém ressaltar que, no começo do governo Figueiredo, a ditadura ainda não tinha data para acabar e o generalpresidente declarou à imprensa que era contrário ao retorno das eleições diretas à presidência da República ${ }^{117}$.

Durante o processo de distensão política, grupos de extrema-direita praticaram dezenas de atentados a bomba e ações de violência contra pessoas, instituições, associações e órgãos da imprensa identificados com a oposição, considerados pelos extremistas como "inimigos da Revolução" e comunistas. A série de atentados, iniciados em 1976, se multiplicaram entre 1978 e 1981, no final do governo Geisel e início do governo Figueiredo (considerado pela extrema-direita o maior "traidor da Revolução"). Nesse período nasce ou renasce inúmeros grupos paramilitares que irão perpetrar inúmeros atentados e ações de violência, como os conhecidos Comando de Caça aos Comunistas (CCC) e Movimento Anticomunista (MAC) - que agiam desde a década de 1960 - e os novos grupos, como o Comando Delta, a Falange Pátria Nova e as Brigadas Moralistas ${ }^{118}$. Todos esses grupos paramilitares de extrema-direita se consideravam "defensores da Revolução de 1964 e combatentes do inimigo comunista".

A “direita explosiva” foi responsável por dezenas de atentados entre 1978 e 1981, com o objetivo de criar pânico e enviar recados aos oposicionistas e ao próprio governo. Um desses atentados vitimou a secretária da OAB, no Rio de Janeiro, Lyda Monteiro da Silva, em agosto de 1980. Outro alvo dos extremistas foram as bancas que vendiam jornais alternativos: dezenas de bancas em várias cidades do país foram atacadas durante a noite. Outro recurso comum dos grupos de extrema-direita era o sequestro de pessoas ligadas à oposição, muitos submetidos a espancamentos. Embora o general-presidente tenha reagido com fortes discursos, na prática houve pouco esforço da ditadura em investigar efetivamente os atentados e em punir os envolvidos, sinalizando para a impunidade da "direita explosiva", como ficou 
explícito no atentado no Riocentro, em $1981^{119}$. O acobertamento do caso contribuiu para o desgaste do governo ${ }^{120}$.

Além da crise econômica e inflacionária, que catalisou a eclosão de dezenas de greves pelo país, os primeiros meses do governo Figueiredo foram marcados pelos debates acerca da anistia política e da reforma político-partidária, que determinaria o fim do bipartidarismo. Contudo, a ditadura militar impôs uma lei de anistia parcial (que excluía os presos políticos e exilados considerados "terroristas"121) e recíproca (que abrangia também os agentes da repressão, visando a evitar o julgamento de militares e civis acusados por violações de direitos humanos e assassinatos), que foi aprovado no Congresso no dia 22 de agosto de 1979.

Em seguida, a ditadura dedicou-se à casuística reforma político-partidária, visando ao retorno do pluripartidarismo e, sobretudo, à fragmentação da oposição reunida no MDB. Entretanto, a reforma não ameaçava apenas desintegrar o MDB, mas também a própria ARENA, uma vez que o partido governista estava longe de ser unido e coeso. Desse modo, a ditadura procurou concentrar seus esforços em garantir que o partido governista não se fragmentasse, preservando a sua base parlamentar, sem causar nenhum efeito negativo à ditadura $^{122}$.

O projeto governamental de reforma político-partidária foi encaminhado no dia 18 de outubro de 1979 ao Congresso, prevendo o fim do bipartidarismo, a dissolução da ARENA e do MDB e contendo as novas normas para a organização dos partidos políticos. Apesar dos protestos do $\mathrm{MDB}$, o projeto de reforma político-partidária foi aprovado no dia 22 de novembro de 1979. Desse modo, ARENA e MDB deixaram de existir como organizações políticas após 13 anos de limitada participação no sistema político implantado pela ditadura militar.

Com o fim do bipartidarismo e o retorno ao pluripartidarismo foram organizados novos partidos políticos em 1980, como o Partido Democrático Social (PDS) ${ }^{123}$, sucedâneo da ARENA; o Partido do Movimento Democrático Brasileiro (PMDB) ${ }^{124}$, herdeiro do MDB; o Partido Popular (PP), organizado por emedebistas "moderados" (liderados por Tancredo Neves) e dissidentes da ARENA (liderados por Magalhães Pinto); o Partido Trabalhista Brasileiro (PTB); o Partido Democrático Trabalhista (PDT), de Leonel Brizola; e o Partido dos Trabalhadores (PT), liderado pelo líder sindical Luís Inácio Lula da Silva.

Se, por um lado, as articulações para a criação do PDS garantiram a maioria parlamentar ao governo no Congresso ${ }^{125}$, por outro, a esperada fragmentação das oposições atingiu significativamente o MDB/PMDB, que perderia 80 deputados federais até o final de 
1981, o equivalente a 42,3\% dos 189 deputados eleitos pelo MDB em 1978. A maioria dos parlamentares que deixaram o MDB/PMDB optou em ingressar no Partido Popular (PP), que recebeu a adesão de 41 deputados oriundos do antigo MDB até o final de 1981. Além do PP, também houve o ingresso de 22 ex-emedebistas no PDS, 10 no PDT, cinco no PT, um no PTB e um indeciso ${ }^{126}$.

As primeiras eleições após o fim do bipartidarismo estavam previstas para 15 de novembro de 1980, quando seriam realizadas as eleições municipais. No entanto, em setembro de 1980, de forma casuística, a ditadura adiou para 1982 as eleições municipais, prorrogando os mandatos dos prefeitos e vereadores (cuja maioria estava vinculada ao PDS). Embora o governo tenha utilizado o argumento de que adiamento era indispensável em virtude da recente reformulação partidária, convém ressaltar que a ditadura temia uma derrota eleitoral em 1980, uma vez que o país enfrentava uma grave crise econômica e inflacionária.

Em novembro de 1980, foi aprovada no Congresso, por unanimidade, uma emenda governamental que restabeleceu as eleições diretas para os governos estaduais em 1982 e extinguiu a votação indireta ao Senado. Contudo, visando a garantir o êxito nas eleições de 1982, a ditadura, em 25 de novembro de 1981, enviou ao Congresso um casuístico projeto de lei sobre a reforma eleitoral (conhecido como "Pacote de Novembro"), proibindo as coligações partidárias e impondo o voto vinculado, obrigando os eleitores a votarem em candidatos do mesmo partido em todos os cargos em disputa, em nível nacional, estadual e municipal. Desse modo, a nova lei eleitoral, que visava a favorecer o PDS e a fragmentar o voto oposicionista, também reduziu as chances de êxito eleitoral dos partidos menores (PP, PTB, PDT e PT), que estavam em processo de organização e estruturação e não teriam condições de apresentar candidatos para todos os cargos.

A partir do "Pacote de Novembro", Tancredo Neves passou a defender a fusão de todas as correntes oposicionistas em uma só legenda. Entretanto, a proposta foi rechaçada por PTB, PDT e PT, sendo acolhida apenas pela maioria dos membros do PP e do PMDB. Assim, em dezembro de 1981, as negociações visando à incorporação do PP ao PMDB se intensificaram. Posteriormente, em 14 de fevereiro de 1982, uma convenção conjunta dos dois partidos concretizou a incorporação do $\mathrm{PP}$ ao $\mathrm{PMDB}^{127}$. Em suma, a incorporação do PP ao PMDB foi uma reação contra o "Pacote de Novembro", fortalecendo o PMDB, que ampliou consideravelmente o número de parlamentares. Por sua vez, o governo e o PDS tentaram impugnar a incorporação junto ao TSE, que, em março de 1982, considerou legal o processo. 
No entanto, as manobras casuísticas da ditadura visando a controlar o processo político e garantir o êxito nas eleições de 1982 não se restringiram ao "Pacote de Novembro". Em maio de 1982, temendo que as oposições conquistassem a maioria no Congresso, o governo restabeleceu a exigência da maioria dos dois terços para a aprovação de emendas constitucionais, além de alterar o critério para a composição do Colégio Eleitoral para as eleições presidenciais, reduzindo as chances da oposição ${ }^{128}$.

Nas eleições, realizadas no dia 15 de novembro de 1982, o PDS elegeu 12 governadores e senadores ${ }^{129}$, enquanto o PMDB elegeu nove ${ }^{130}$ e o PDT venceu com Leonel Brizola no Rio de Janeiro. No Senado, o PDS garantiu a manutenção da maioria parlamentar, porém perderia a maioria na Câmara dos Deputados. Embora o PDS tenha elegido 235 deputados contra 200 do PMDB, as oposições unidas somavam 244 parlamentares $^{131}$. Nos estados, o PDS ainda conquistou a maioria parlamentar em 13 assembleias estaduais ${ }^{132}$.

Em 1983, o processo de decrepitude da ditadura se acentuou em virtude do agravamento da crise econômica e social e do aumento da insatisfação da sociedade civil, dando início ao processo de transição pactuada, realizado entre os militares, os setores conservadores e os setores moderados da oposição, que resultou na transição do regime ditatorial-militar para o regime liberal-democrático, Nesse período de transição (1985-1989), correspondente ao governo do civil José Sarney, ocorreram a formação da Assembleia Nacional Constituinte (1987-1988), a promulgação da Constituição de 1988 e as eleições direitas de 1989 à presidência da República. Desse modo, somente em março de 1990, com a posse do presidente eleito Fernando Collor de Mello, efetivamente tem início o regime liberal-democrático no país.

\section{Considerações Finais}

A ditadura militar de Segurança Nacional implantada no Brasil em 1964 procurou legitimar-se por meio de um contraditório arcabouço jurídico-institucional que, apesar da aparência de legalidade, impôs um sistema de censura, vigilância e repressão baseado no Terrorismo de Estado. Ao hipertrofiar os poderes dos generais-presidentes e restringir a autonomia do Legislativo e do Judiciário, o regime procurou camuflar a ditadura, inclusive criando um simulacro de democracia, caracterizado por um sistema político bipartidário artificial, por inúmeros casuísmos, pelas eleições indiretas e o jogo de cartas marcadas, pelas cassações de políticos dissidentes e oposicionistas e pelo fechamento temporário do Congresso em três oportunidades. 
Portanto, os discursos que negam a ditadura militar no Brasil - se utilizando de argumentos de que havia eleições e partidos políticos, de que o Congresso e o Judiciário não foram fechados, por exemplo - são sofismas. Os saudosistas do regime militar, que geralmente utilizam o discurso oficial de que a "revolução de 1964 salvou o Brasil do golpe comunista" e de que a repressão apenas atingiu os "terroristas e subversivos", também tentam manipular deliberadamente a história, afirmando embustes tais como a ausência da inflação, da corrupção e da criminalidade durante o período dos generais-presidentes. Nesse sentido, Eric Hobsbawm alerta para o "mau uso" intencional que muitas vezes se faz da história: "Se não há nenhum passado satisfatório, sempre é possível inventá-lo"133. Afinal, a criação de um passado idealizado e romantizado, uma espécie de época de ouro perdida, é uma construção intencional que visa a atender determinados objetivos políticos e ideológicos. E os apologistas da ditadura militar não escondem a sua vertente autoritária e antidemocrática, além da paranoia anticomunista.

\section{Notas}

\footnotetext{
${ }^{1}$ As ditaduras instauradas na América Latina nas décadas de 1960 e 1970 foram regimes de Segurança Nacional, baseados na Doutrina de Segurança Nacional (DSN), elaborada pelos Estados Unidos no contexto da Guerra Fria e difundidas nas Escolas de Guerras dos países latino-americanos. De acordo com Ananda Simões Fernandes, "a DSN fundamentava-se na necessidade da segurança nacional para a defesa dos valores cristãos e democráticos do mundo ocidental, como uma resposta ao "comunismo ateu". Tendo como base um virulento anticomunismo, todas as manifestações sociais e políticas de contestação passaram a ser identificadas como "subversão comunista", justificando todo e qualquer tipo de repressão. Ananda Simões Fernandes $(2009$, p. 838) lembra que a flexibilização do conceito de comunismo, ou seja, a sua amplitude, é a base ideológica para fundamentar um dos conceitos-chave da DSN: o do "inimigo interno". Partindo da premissa de que o comunismo não seria estimulado via uma agressão externa, mas, sim, insuflado dentro das fronteiras nacionais de cada país, esse conceito é fundamental para explicar e legitimar as medidas tomadas pelos governos ditatoriais. In: FERNANDES, Ananda Simões. A reformulação da Doutrina de Segurança Nacional pela Escola Superior de Guerra no Brasil: a geopolítica de Golbery do Couto e Silva. Antítese. Londrina, v. 2, n. 4, 2009, p. 837.

${ }^{2}$ A ditadura decretou 17 Atos Institucionais, 104 Atos Complementares, 11 decretos-secretos e mais de dois mil decretos-leis, que constituíram a tessitura principal do emaranhado de leis que marcaram a consolidação dos princípios autoritários brasileiros. In: NAPOLITANO, Marcos. 1964: história do regime militar brasileiro. São Paulo: Contexto, 2014, p. 80.

${ }^{3}$ KINZO, Maria D’Alva Gil. Oposição e autoritarismo: gênese e trajetória do MDB (1966-1979). São Paulo: Vértice, 1988, p. 15-17.

${ }^{4}$ Idem, p. 17.

${ }^{5}$ Cf. CODATO, Adriano Nervo. Uma história política da transição brasileira: da ditadura militar à democracia. Revista de Sociologia e Política. Curitiba, n. 25, nov. 2005, p. 83-106.

${ }^{6}$ Guilhermo O’Donnell distingue duas formas clássicas de transição: a transição por colapso: rápida, com forte ruptura com o autoritarismo vigente (ocorreu na Grécia, Argentina e Bolívia, por exemplo); e a transição pactuada: lenta e gradual, segura para as forças até então no poder, fruto de acordo entre os setores conservadores no poder e as forças moderadas na oposição (ocorreu na Espanha, Chile e Brasil, por exemplo). Apud SILVA, Francisco Carlos Teixeira da. Crise da ditadura militar e o processo de abertura política no Brasil, 1974-1985. In: FERREIRA, Jorge; DELGADO, Lucilia de Almeida Neves (Orgs.). O Brasil republicano: o tempo da ditadura. Rio de Janeiro: Civilização Brasileira, 2003, v. 4, p. 273.
} 


\begin{abstract}
${ }^{7}$ A doutrina da guerra revolucionária (Guerre Révolutionnaire) foi uma concepção militar francesa desenvolvida a partir da experiência na guerra da Indochina (1946-1954) e aprimorada após a Batalha de Argel (1957). Tratava-se de uma doutrina para uma guerra não convencional e que exigira a adoção de métodos não convencionais. Conforme João Roberto Martins Filho, "a principal característica desta forma de conflito era a indistinção entre os meios militares e os não militares e a particular combinação entre política, ideologia e operações bélicas que ela proporcionava", com a utilização coordenada de todos os recursos no combate ao inimigo invisível e interno. In: MARTINS FILHO, João Roberto. A educação dos golpistas: cultura militar, influência francesa e golpe de 1964. Paper apresentado no Internacional Symposium "The cultures dictatoryship: Historical reflections on the Brazilian golpe of 1964". Maryland, University of Maryland, 2004, p. 41.

${ }^{8} \mathrm{O}$ conceito de "inimigo interno" era propositalmente difuso, elástico e funcional, ampliando os "círculos de terror": quanto mais indefinido era o seu contorno, mas refém ficava a população dessa lógica, pois qualquer um poderia ser enquadrado como "inimigo" ("subversivo" ou "comunista"). E para se defender desse inimigo, não há diferenciação entre violência preventiva e violência repressiva. Assim, passa-se a viver uma guerra interna, possibilitando à repressão estatal justificar a sua razão de ser. In: PADRÓS, Enrique Serra. Terrorismo de Estado: reflexões a partir das experiências das Ditaduras de Segurança Nacional. In: GALLO, Carlos Arthur; RUBERT, Silvania (Orgs.). Entre a memória e o esquecimento: estudos sobre os 50 anos do golpe civil-militar
\end{abstract} no Brasil. Porto Alegre: Deriva, 2014, p. 21.

${ }^{9}$ BONASSO, Miguel. Prefácio. In: PIETERSE, Jan et al. Terrorismo de Estado. El papel internacional de EEUU. Navarra: Txalaparta, 1990, p. 9.

${ }^{10}$ PADRÓS, op. cit., p. 13.

${ }^{11}$ A imposição do medo procurou causar paralisia, resignação, silenciamento e graus de colaboracionismo - uma das formas mais desejadas de quebra da espinha moral, política e ética das organizações de resistência e de oposição. In: PADRÓS, op. cit., p. 21.

${ }_{12}$ Trata-se dos principais governadores que participaram do golpe de 1964, como Carlos Lacerda (Guanabara), José de Magalhães Pinto (Minas Gerais), Adhemar de Barros (São Paulo), Ildo Meneghetti (Rio Grande do Sul), Ney Braga (Paraná), Mauro Borges (Goiás), entre outros.

${ }^{13}$ De acordo com Carlos Fico, a conspiração para a derrubada de João Goulart começou em 1963, quando diversas "ilhas de conspiração" civis e militares se espalharam pelo Brasil, ainda que sem maior coordenação e isoladas. No entanto, o marechal Castelo Branco, então chefe do Estado-Maior do Exército, tomou a iniciativa que faltava para coordenar, entre os militares, as forças que conspiravam pela derrubada de Goulart, expedindo um memorando aos seus subordinados em 20 de março de 1964. A coalizão de conspiradores civis e militares resultou no golpe civil-militar de 1964. Cf. FICO, Carlos. O golpe de 1964: momentos decisivos. Rio de Janeiro: FGV, 2014.

${ }^{14}$ Cf. CHAGAS, Carlos. A guerra das estrelas (1964-1984): os bastidores das sucessões presidenciais. 4. ed. Porto Alegre: L\&PM, 1985, p. 60-67.

${ }^{15}$ FICO, op. cit., 2014, p. 97-101.

${ }^{16} \mathrm{Na}$ composição dos seus ministérios, Castelo Branco não conseguiu deixar de manter o general Arthur da Costa e Silva como ministro da Guerra.

${ }^{17}$ Criada em 1949 pelos setores do Exército brasileiro que haviam participado, juntamente com as forças norteamericanas, da Segunda Guerra Mundial por meio da Força Expedicionária Brasileira (FEB), a ESG, sob a égide da Doutrina de Segurança Nacional, se tornou bastião do anticomunismo e elaborou um projeto para o Brasil com base no lema segurança e desenvolvimento. Também defendia o livre comércio e uma posição pró-Estados Unidos. In: BORGES, Nilson. A Doutrina de Segurança Nacional e os governos militares. In: FERREIRA, Jorge; DELGADO, Lucilia de Almeida Neves (Orgs.). O Brasil republicano: o tempo da ditadura. Rio de Janeiro: Civilização Brasileira, 2003, v. 4, p. 36.

${ }^{18}$ CHIRIO, Maud. A política nos quarteis: revoltas e protestos de oficiais na ditadura militar brasileira. Rio de Janeiro: Zahar, 2012, p. 50.

${ }^{19}$ Idem, p. 50-51.

${ }^{20}$ Nesse sentido, surgiram as teses da "ditabranda" ou de uma "ditadura envergonhada", salientando o "caráter reativo e brando do regime entre 1964 e 1968. Os defensores dessa tese afirmam que os quatro primeiros anos do regime (até o AI-5) foram caracterizados pela existência do recurso ao habeas corpus e por uma relativa liberdade de imprensa, de expressão e de manifestação. Nessa linha de raciocínio, o regime fechou-se, por meio do AI-5, por sucumbir às pressões da extrema-direta militar ("linha dura") e à conjuntura política marcada pelo crescimento da oposição ao governo militar em 1968. In: NAPOLITANO, op. cit., p. 69-70.

${ }^{21}$ NAPOLITANO, op. cit., p. 73.

${ }^{22}$ Os numerosos casos de torturas no nordeste e em outras partes do país foram denunciados na imprensa e no livro Tortura e torturados, do jornalista Márcio Moreira Alves, publicado em 1966. 
${ }^{23}$ FICO, Carlos. Versões e controvérsias sobre 1964 e a ditadura militar. Revista Brasileira de História. São Paulo, v. 24, n. 47, 2004, p. 33.

${ }^{24}$ CHIRIO, op. cit., p. 48.

${ }^{25}$ Ver Relatório da Comissão Nacional da Verdade (2014) e Dossiê dos mortos e desaparecidos políticos a partir de 1964 (1995).

${ }^{26}$ NAPOLITANO, op. cit., p. 73

${ }^{27}$ As eleições de 3 de outubro de 1965, nas qual seriam eleitos os novos governadores de 11 estados, foram as últimas eleições diretas aos governos estaduais, uma vez que o Ato Institucional $\mathrm{n}^{\circ} 3$ (AI-3), de 5 de fevereiro de 1966, estabeleceu que as eleições para os governos estaduais seriam indiretas. As eleições diretas para os governos estaduais só retornaram em 1982.

${ }^{28}$ FICO, op. cit., 2014, p. 118

${ }^{29}$ KINZO, op. cit., p. 24.

${ }^{30}$ Idem.

${ }^{31}$ Idem, p. 27.

${ }^{32}$ MARTINS FILHO, João Roberto. O palácio e a caserna: a dinâmica militar das crises políticas na ditadura (1964-1969). São Carlos: EDUFSCar, 1995, p. 72.

${ }^{33}$ Idem, p. 66-67.

${ }^{34}$ Em virtude do AI-3 de 5 de fevereiro de 1966, os prefeitos das capitais passaram a ser nomeados pelos governadores, que passaram a ser eleitos indiretamente.

35 GRINBERG, Lucia. Partido político ou bode expiatório: um estudo sobre a Aliança Renovadora Nacional (Arena), 1965-1979. Rio de Janeiro: Mauad X, 2009, p. 64.

${ }^{36}$ MOTTA, Rodrigo Patto Sá. Introdução à história dos partidos políticos brasileiros. 2. ed. Belo Horizonte: UFMG, 2008, p. 99-100.

${ }^{37}$ KINZO, op. cit., p. 32-35.

${ }^{38}$ Convém ressaltar que, na época, os golpistas civis e militares chamaram o golpe de 1964 de "revolução" e o governo ditatorial instituído a partir 1964 de "revolucionário".

${ }^{39}$ MARTINS FILHO, op. cit., 1995, p. 74-75.

${ }^{40}$ Em 1966, ocorreram eleições indiretas para os governos estaduais do Rio Grande do Sul, São Paulo, Rio de Janeiro, Espírito Santo, Bahia, Pernambuco, Ceará, Alagoas, Sergipe, Piauí, Amazonas e Acre.

${ }^{41}$ Cf. Gazeta do Povo, Curitiba, 4 out. 1966, p. 1 e 3.

${ }^{42}$ GRINBERG, op. cit., p. 101.

${ }^{43}$ KINZO, op. cit., p. 74.

${ }^{44}$ A nova Carta passou a vigorar a partir de 15 de março de 1967, mesma data da posse do general Costa e Silva e dos parlamentares no Congresso Nacional.

${ }^{45}$ NAPOLITANO, op. cit., p. 80.

${ }^{46}$ Castelo Branco faleceu poucos meses após deixar a presidência em um acidente aéreo ocorrido em 18 de julho de 1967.

${ }^{47}$ Carlos Lacerda, um dos principais articuladores do golpe civil-militar de 1964 e que ambicionava chegar à presidência da República, rompeu com Castelo Branco a partir da decretação do AI-2 e com o estabelecimento das eleições indiretas à presidência. Após o AI-2, Lacerda optou em não ingressar na ARENA e tentou articular a criação de um terceiro partido, denominado Partido da Renovação Democrática (PAREDE), que teve o seu registro indeferido pela Justiça Eleitoral em maio de 1966. A partir do segundo semestre de 1966, Lacerda ingressou definitivamente ao lado das forças oposicionistas e passou a ser um dos principais articuladores de um movimento de oposição à ditadura denominado Frente Ampla.

${ }^{48}$ A Frente Ampla nasceu oficialmente no dia 28 de outubro de 1966 por meio de um Manifesto assinado por Carlos Lacerda e publicado no jornal carioca Tribuna da Imprensa. Juscelino Kubitschek ingressou na Frente Ampla em novembro de 1966, após um encontro com Lacerda em Lisboa, que resultou na divulgação de uma nota conjunta conhecida como Declaração de Lisboa. Por sua vez, João Goulart somente ingressou na Frente Ampla em setembro de 1967, após reunir-se com Lacerda em Montevidéu, que resultou na divulgação, em 25 de setembro de 1967, do Pacto de Montevidéu. A entrada de João Goulart na Frente Ampla revigorou o movimento, impulsionando a adesão dos trabalhistas e de emedebistas ao movimento. In: DELGADO, Márcio de Paiva. $A$ Frente Ampla de oposição ao regime militar (1966-1968). Tese (Doutorado em História) - Universidade Federal de Minas Gerais, Belo Horizonte, 2013, p. 175-178.

${ }^{49} \mathrm{O}$ deputado Márcio Moreira Alves, indignado com a repressão policial contra as manifestações estudantis e a violenta ocupação militar da Universidade de Brasília (UnB) no final de agosto, fez um discurso no Congresso, no dia 2 de setembro de 1968, no qual criticou o Exército e os abusos praticados pelos órgãos de segurança. O deputado, que era jornalista e autor do livro Torturas e torturados, solicitou que os estudantes boicotassem o desfile do dia 7 de setembro e que as moças boicotassem os jovens oficiais. Além disso, em seu discurso, Márcio 
Moreira Alves chamou os policiais de bando de facínoras e fez referência ao Exército como um valhacouto de torturadores. Entretanto, os ministros militares das três Armas consideraram o discurso ofensivo às Forças Armadas e exigiram que os deputados Márcio Moreira Alves e Hermano Alves - acusado de ter publicado artigos, no jornal carioca Correio da Manhã, também considerados difamatórios às Forças Armadas - fossem processados na Lei de Segurança Nacional. Desse modo, a partir de setembro de 1968, a ditadura passou a pressionar a Câmara dos Deputados para conceder a licença - conforme previa a Constituição de 1967 - para processar os deputados emedebistas, dando início a uma crise entre os poderes Executivo e Legislativo, que, em seção extraordinária realizada no dia 12 de dezembro, negou o pedido para processar Márcio Moreira Alves e Hermano Alves. In: MOTTA, Rodrigo Patto Sá. Sobre as origens e motivações do Ato Institucional 5. Revista Brasileira de História. São Paulo, v. 38, n. 79, 2018, p. 195-216.

${ }^{50}$ NAPOLITANO, op. cit., p. 94.

${ }^{51}$ CODATO, Adriano Nervo. O golpe de 1964 e o regime de 1968: aspectos conjunturais e variáveis históricas. História: Questões \& Debates. Curitiba, n. 40, 2004, p. 28.

${ }^{52} \mathrm{O}$ denominador comum, que permitiu a união dos vários grupos militares, era o anticomunismo. Conforme Adriano Codato, "o anticomunismo consistia, provavelmente, no elemento ideológico mais renitente da visão militar de mundo desde 1935 e funcionou, na conjuntura, como um mínimo denominador comum a todas as correntes castrenses”. In: CODATO, op. cit., 2004, p. 29.

${ }^{53}$ MOTTA, op. cit., 2018, p. 211.

${ }^{54}$ Idem, p. 209.

${ }^{55}$ O Congresso ficou em recesso de dezembro de 1968 a outubro de 1969.

${ }^{56}$ DELGADO, op. cit., p. 212-216.

${ }^{57}$ GRINBERG, op. cit., p. 128.

${ }^{58}$ Com o estado de saúde debilitado, Arthur da Costa e Silva faleceu em 17 de dezembro de 1969.

${ }^{59}$ Cf. SKIDMORE, Thomas. Brasil: de Castelo a Tancredo. 4. ed. Rio de Janeiro: Paz e Terra, 1988.

${ }^{60}$ Idem, p. 211.

${ }^{61}$ Cf. Gazeta do Povo, Curitiba, 26 out. 1969, p. 1.

${ }^{62}$ GRINBERG, op. cit., 145-149.

${ }^{63}$ MOTTA, op. cit., 2008, p. 97.

${ }^{64}$ No entanto, convém ressaltar os limites do "milagre brasileiro", caracterizado pelo aumento da concentração de renda e pelo arrocho salarial, que teve um alto custo social, pois o projeto "Brasil Grande Potência" não levou em consideração questões como equidade ou melhoria das condições de vida da população, caracterizando-se pelos altos índices de extrema pobreza, mortalidade infantil e analfabetismo. Ademais, o "milagre brasileiro" durou pouco, pois, a partir do segundo semestre de 1973, a inflação voltaria a crescer, uma vez que a economia brasileira sentiu os efeitos da crise internacional do petróleo. In: FICO, Carlos. História do Brasil contemporâneo: da morte de Vargas aos dias atuais. São Paulo: Contexto, 2015, p. 80-81.

${ }^{65}$ Idem, p. 82. Mais detalhes, ver também: FICO, Carlos. Reinventando o otimismo: ditadura, propaganda e imaginário social no Brasil. Rio de Janeiro: FGV, 1997; FICO, Carlos. Espionagem, polícia política, censura e propaganda: os pilares básicos da repressão. In: FERREIRA, Jorge; DELGADO, Lucilia de Almeida Neves (Orgs.). O Brasil republicano: o tempo da ditadura. Rio de Janeiro: Civilização Brasileira, 2003, v. 4, p. 167206.

${ }^{66}$ NAPOLITANO, op. cit., p. 128.

${ }^{67}$ Idem, p. 131.

${ }^{68}$ Trata-se do Centro de Informações da Marinha (CENIMAR), criado em 1955; do Centro de Informações do Exército (CIE), criado em 1967; e do Centro de Informações e Segurança da Aeronáutica (CISA), criado em 1968.

${ }^{69}$ O DOI era o braço armado do CODI. Os DOIs eram destacamentos de combate, captura e interrogatório, no qual a tortura era frequentemente utilizada. Por sua vez, os CODIs visavam a articular todos os quadros e agências encarregadas da repressão em uma determinada área. In: NAPOLITANO, op. cit.,p. 134-135.

${ }^{70}$ Cf. NAPOLITANO, op. cit., p. 132-134.

${ }^{71}$ Em novembro de 1969, Carlos Marighella foi morto em São Paulo. Em setembro de 1971, Carlos Lamarca foi morto no interior da Bahia. Entre 1972-1974, o governo aniquilou os guerrilheiros do PCdoB na região do Araguaia, no sul do Pará. Desse modo, em 1975 a luta armada estava definitivamente derrotada no Brasil.

${ }^{72}$ NAPOLITANO, op. cit., p. 135.

${ }^{73}$ FICO, op. cit., 2015, p. 82-83.

${ }^{74}$ KINZO, op. cit., p. 74.

${ }^{75}$ Idem, p. 133-134.

${ }^{76}$ MOTTA, op. cit., 2008, p. 97.

${ }^{77}$ KINZO, op. cit., p. 134-135. 
${ }_{78}$ Idem, p. 138-141.
${ }^{79}$ MOTTA, Rodrigo Patto Sá. O MDB e as esquerdas. In: FERREIRA, Jorge; REIS, Daniel Aarão (Orgs.). As
esquerdas no Brasil: revolução e democracia (1964-...). Rio de Janeiro: Civilização Brasileira, 2007, v. 3, p. 290.
${ }^{80}$ PALMEIRA, André Franklin. O Partido do Brasil: uma história do Partido do Movimento Democrático Brasileiro (1980-2016). Tese (Doutorado em História Social) - Universidade Federal Fluminense, Niterói, 2017, p. 55 .

${ }^{81}$ SKIDMORE, op. cit., p. 299.

${ }^{82}$ KINZO, op. cit., p. 145-146.

${ }^{83}$ Convém ressaltar que o general-presidente Geisel explicitou os limites da distensão, quando declarou, em $1^{\circ}$ de agosto de 1975, que não pretendia revogar o AI-5 e o Decreto-Lei no 477 , nem revisar a Lei de Segurança Nacional, nem promulgar a anistia e nem reduzir as prerrogativas do poder Executivo. In: NAPOLITANO, op. cit., p. 247.

${ }^{84}$ Cf. NAPOLITANO, op. cit., p. 234-235; CHIRIO, op. cit., p. 173-174.

${ }^{85}$ KINZO, op. cit., p. 155-156.

${ }^{86}$ O MDB elegeu os senadores nos seguintes estados: São Paulo, Rio de Janeiro, Guanabara, Minas Gerais, Rio Grande do Sul, Paraná, Santa Catarina, Espírito Santo, Goiás, Pernambuco, Ceará, Rio Grande do Norte, Sergipe, Paraíba, Amazonas e Acre. Por sua vez, a ARENA elegeu os senadores na Bahia, Piauí, Alagoas, Maranhão, Pará e Mato Grosso.

${ }^{87}$ KINZO, op. cit., p. 74.

${ }^{88}$ As seis Assembleias Legislativas estaduais que o MDB elegeu a maioria dos deputados foram em São Paulo, no Rio de Janeiro, na Guanabara, no Rio Grande do Sul, no Amazonas e no Acre.

${ }^{89}$ MOTTA, op. cit., 2008, p. 100-101.

${ }^{90}$ CHIRIO, op. cit, p. 234-235.

${ }^{91}$ Idem, p. 195

${ }^{92}$ Idem, p. 184

93 A repressão continuou violenta durante o governo Geisel, com as práticas de torturas, assassinatos e desaparecimentos de oposicionistas - tidas pelo "moderado" e "liberal" general-presidente Ernesto Geisel como um "mal necessário". In: FICO, op. cit., 2015, p. 86.

${ }^{94}$ NAPOLITANO, op. cit., p. 252.

${ }^{95}$ FICO, op. cit., 2014, p. 106.

96 As denúncias dos casos de torturas, assassinatos e desaparecimentos da oposição armada e desarmada se acentuaram e ultrapassaram as fronteiras do país, com os Estados Unidos (no governo de Jimmy Carter) reconhecendo que o Brasil praticava violações dos direitos humanos.

${ }^{97}$ NAPOLITANO, op. cit., p. 269.

${ }^{98}$ CHIRIO, op. cit., p. 186-187.

99 Idem, p. 189-190.

${ }^{100}$ Em 15 de novembro de 1976, a sede do jornal alternativo Opinião, no Rio de janeiro, sofreu um atentado a bombas.

${ }^{101}$ CHIRIO, op. cit., p. 188.

102 A Lei Falcão vigorou até 1985.

103 Em 1976, foram cassados os deputados federais Alberto Marcelo Gatto (MDB/SP), Amaury Muller (MDB/RS), Nadyr Rossetti (MDB/RS) e Lysâneas Maciel (MDB/RJ).

${ }^{104}$ KINZO, op. cit., p. 176.

105 Idem, p. 181.

${ }^{106}$ Idem, p. 182-183.

107 Idem, p. 191.

108 Acusado de ler um discurso no plenário oriundo do jornal Voz Operária (do PCB) e de ser porta-voz dos comunistas, Marcos Tito foi cassado pelo AI-5 em 14 de junho de 1977.

${ }^{109}$ Cassado pelo AI-5 no dia 30 de junho de 1977, José Alencar Furtado havia protestado - em 27 de junho, durante um programa do MDB na televisão e no rádio, que obteve um grande índice de audiência - contra as cassações dos seus colegas de partido e criticou a repressão e o desaparecimento de presos políticos.

${ }^{110}$ KINZO, op. cit., p. 194-195.

${ }^{111}$ Idem, p.195-196.

112 NAPOLITANO, op. cit., p. 269.

${ }_{113}$ KINZO, op. cit., p. 198.

${ }^{114}$ Idem, p. 198-199.

115 O MDB venceu as eleições para o Senado em São Paulo, Rio de Janeiro, Minas Gerais, Rio Grande do Sul, Santa Catarina, Paraná, Goiás e Paraíba. 
${ }^{116}$ KINZO, op. cit., p. 201-202.

${ }^{117} \mathrm{O}$ general-presidente João Batista Figueiredo declarou que, se dependesse dele, jamais seriam reestabelecidas no Brasil as eleições diretas à presidência da República, devendo ser eternizado o sistema de eleições indiretas. In: Gazeta do Povo, Curitiba, 9 nov. 1979, p. 1.

${ }^{118}$ CHIRIO, op. cit., p. 188.

${ }^{119} \mathrm{Na}$ noite de 30 de abril de 1981, dois agentes do DOI-CODI, do Rio de Janeiro, planejaram um atentado no Riocentro, onde ocorria um show de MPB com artistas símbolos da oposição (como Chico Buarque), que reuniu milhares de jovens. Porém, uma das bombas explodiu dentro do carro dos agentes quando era preparada, matando o sargento Guilherme Ferreira do Rosário e ferindo o capitão Wilson Luís Chaves Machado.

${ }^{120}$ NAPOLITANO, op. cit., p. 294-295.

${ }^{121}$ No entanto, na prática, estes presos políticos acabaram sendo libertados por outros recursos jurídicos, como revisões de pena e indultos. In: NAPOLITANO, op. cit., p. 299.

${ }^{122}$ KINZO, op. cit., p. 205-206.

123 A nova nomenclatura do partido governista foi uma estratégia eleitoral que visava a distanciar-se da já desgastada e impopular ARENA, além de dar ao eleitor a impressão de que o PDS era um partido diferente e moderno, preocupado com as demandas sociais e democráticas da sociedade civil. In: MOTTA, op. cit., 2008, p. 105.

${ }^{124}$ O PMDB procurou conservar a popularidade e o capital político da antiga sigla (MDB), apenas acrescentando a palavra "Partido" para atender às exigências da nova lei. Desse modo, a sigla PMDB possibilitou que o eleitorado o reconhecesse como uma continuidade do extinto MDB na luta contra o autoritarismo e pelo restabelecimento da democracia. In: MOTTA, op. cit., 2008, p. 105-106.

${ }^{125}$ Embora o partido governista tenha perdido 38 deputados até o final de 1981, compensou a perda com a cooptação de 22 deputados da ala adesista do MDB, o que garantiu ao PDS contar com 215 (51,2\%) cadeiras na Câmara dos Deputados. Entre os 38 deputados eleitos pela ARENA em 1978 e que optaram em não ingressar no PDS, verifica-se que 28 vincularam-se ao PP, seis no PMDB, três no PTB e um manteve-se indeciso. In: KINZO, op. cit., p. 209.

${ }^{126}$ KINZO, op. cit., p. 209.

${ }^{127}$ Durante a convenção, Ulysses Guimarães foi reeleito presidente nacional do PMDB. Por sua vez, Tancredo Neves foi eleito primeiro vice-presidente da Executiva Nacional do partido. Embora a maioria dos pepistas tenha ingressado no PMDB, alguns não aceitaram a incorporação e optaram por vincular-se ao PDS, como Magalhães Pinto. In: Gazeta do Povo, Curitiba, 15 fev. 1982, p. 1 e 7.

${ }^{128}$ KINZO, op. cit., p. 213.

${ }^{129}$ O PDS elegeu os governadores e senadores no Rio Grande do Sul, Santa Catarina, Mato Grosso e nos nove estados do nordeste.

${ }^{130}$ O PMDB elegeu os governadores e senadores em São Paulo, Minas Gerais, Paraná, Espírito Santo, Goiás, Mato Grosso do Sul, Pará, Amazonas e Acre.

131 Além dos 200 deputados federais eleitos pelo PMDB, o PDT elegeu 23, o PTB elegeu 13 e o PT elegeu 8 parlamentares. In: KINZO, op. cit., p. 214.

${ }^{132}$ KINZO, op. cit., p. 213)

${ }^{133}$ HOBSBAWM, Eric. Sobre história. São Paulo: Cia das Letras, 1998, p. 17.

\section{Referências}

ALVES, Márcio Moreira. Torturas e torturados. Rio de Janeiro: Idade Nova, 1966.

AZEVEDO, Débora B. de; RABAT, Márcio Nuno. Parlamento mutilado: deputados federais cassados pela ditadura de 1964. Brasília: Câmara dos Deputados, 2012.

BONASSO, Miguel. Prefácio. In: PIETERSE, Jan et al. Terrorismo de Estado. El papel internacional de EEUU. Navarra: Txalaparta, 1990. 
BORGES, Nilson. A Doutrina de Segurança Nacional e os governos militares. In: FERREIRA, Jorge; DELGADO, Lucilia de Almeida Neves (Orgs.). O Brasil republicano: o tempo da ditadura. Rio de Janeiro: Civilização Brasileira, 2003, v. 4, p. 13-42.

BRASIL. Relatório da Comissão Nacional da Verdade. Brasília: CNV, 2014.

CHAGAS, Carlos. A guerra das estrelas (1964-1984): os bastidores das sucessões presidenciais. 4. ed. Porto Alegre: L\&PM, 1985.

CHIRIO, Maud. A política nos quarteis: revoltas e protestos de oficiais na ditadura militar brasileira. Rio de Janeiro: Zahar, 2012.

CODATO, Adriano Nervo. O golpe de 1964 e o regime de 1968: aspectos conjunturais e variáveis históricas. História: Questões \& Debates. Curitiba, n. 40, 2004, p. 11-36.

CODATO, Adriano Nervo. Uma história política da transição brasileira: da ditadura militar à democracia. Revista de Sociologia e Política. Curitiba, n. 25, nov. 2005, p. 83-106.

COMISSÃO DE FAMILIARES DE MORTOS E DESAPARECIDOS POLÍTICOS et. al. Dossiê dos mortos e desaparecidos políticos a partir de 1964. Recife: Companhia Editora de Pernambuco, 1995.

DELGADO, Márcio de Paiva. A Frente Ampla de oposição ao regime militar (1966-1968). Tese (Doutorado em História) - Universidade Federal de Minas Gerais, Belo Horizonte, 2013.

FERNANDES, Ananda Simões. A reformulação da Doutrina de Segurança Nacional pela Escola Superior de Guerra no Brasil: a geopolítica de Golbery do Couto e Silva. Antítese. Londrina, v. 2, n. 4, 2009, p. 831-856.

FICO, Carlos. Reinventando o otimismo: ditadura, propaganda e imaginário social no Brasil. Rio de Janeiro: FGV, 1997.

FICO, Carlos. Espionagem, polícia política, censura e propaganda: os pilares básicos da repressão. In: FERREIRA, Jorge; DELGADO, Lucilia de Almeida Neves (Orgs.). O Brasil republicano: o tempo da ditadura. Rio de Janeiro: Civilização Brasileira, 2003, v. 4, p. 167206.

FICO, Carlos. Versões e controvérsias sobre 1964 e a ditadura militar. Revista Brasileira de História. São Paulo, v. 24, n. 47, 2004, p. 29-60.

FICO, Carlos. O golpe de 1964: momentos decisivos. Rio de Janeiro: FGV, 2014. 
FICO, Carlos. História do Brasil contemporâneo: da morte de Vargas aos dias atuais. São Paulo: Contexto, 2015.

GRINBERG, Lucia. Partido politico ou bode expiatório: um estudo sobre a Aliança Renovadora Nacional (Arena), 1965-1979. Rio de Janeiro: Mauad X, 2009.

HOBSBAWM, Eric. Sobre história. São Paulo: Cia das Letras, 1998.

KINZO, Maria D’Alva Gil. Oposição e autoritarismo: gênese e trajetória do MDB (19661979). São Paulo: Vértice, 1988.

MARTINS FILHO, João Roberto. O palácio e a caserna: a dinâmica militar das crises políticas na ditadura (1964-1969). São Carlos: EDUFSCar, 1995.

MARTINS FILHO, João Roberto. A educação dos golpistas: cultura militar, influência francesa e golpe de 1964. Paper apresentado no Internacional Symposium "The cultures dictatoryship: Historical reflections on the Brazilian golpe of 1964". Maryland, University of Maryland, 2004.

MOTTA, Rodrigo Patto Sá. O MDB e as esquerdas. In: FERREIRA, Jorge; REIS, Daniel Aarão (Orgs.). As esquerdas no Brasil: revolução e democracia (1964-...). Rio de Janeiro: Civilização Brasileira, 2007, v. 3, p. 283-303.

MOTTA, Rodrigo Patto Sá. Introdução à história dos partidos políticos brasileiros. 2. ed. Belo Horizonte: UFMG, 2008.

MOTTA, Rodrigo Patto Sá. Sobre as origens e motivações do Ato Institucional 5. Revista Brasileira de História. São Paulo, v. 38, n. 79, 2018, p. 195-216.

NAPOLITANO, Marcos. 1964: história do regime militar brasileiro. São Paulo: Contexto, 2014.

PADRÓS, Enrique Serra. Terrorismo de Estado: reflexões a partir das experiências das Ditaduras de Segurança Nacional. In: GALLO, Carlos Arthur; RUBERT, Silvania (Orgs.). Entre a memória e o esquecimento: estudos sobre os 50 anos do golpe civil-militar no Brasil. Porto Alegre: Deriva, 2014, p. 13-36.

PALMEIRA, André Franklin. O Partido do Brasil: uma história do Partido do Movimento Democrático Brasileiro (1980-2016). Tese (Doutorado em História Social) - Universidade Federal Fluminense, Niterói, 2017. 
SILVA, Francisco Carlos Teixeira da. Crise da ditadura militar e o processo de abertura política no Brasil, 1974-1985. In: FERREIRA, Jorge; DELGADO, Lucilia de Almeida Neves (Orgs.). O Brasil republicano: o tempo da ditadura. Rio de Janeiro: Civilização Brasileira, 2003, v. 4, p. 243-282.

SKIDMORE, Thomas. Brasil: de Castelo a Tancredo. 4. ed. Rio de Janeiro: Paz e Terra, 1988. 